\title{
WHAT LANGUAGE DO EMPLOYERS SPEAK? ON RECENT ANGLICISMS IN THE NAMES OF THE MOST POPULAR PROFESSIONS ADVERTISED ON THE INTERNET
}

\author{
Milan D. Milanovic, ${ }^{*}$ Ana D. Milanovic \\ Faculty of Philology and Arts, University of Kragujevac, Kragujevac, Serbia
}

In this paper, the titles of the most popular professions advertised on the Internet are analyzed for the purpose of identifying those titles which can be classified as a certain type of recent anglicisms. The classification of anglicisms is performed in line with the typology suggested by Prćic (2005), who, based on the form they take, distinguishes between raw, obvious, and hidden anglicisms, indicating the degree of their adaptation within the system of the Serbian language. The following hypotheses are tested by applying a corpus analysis: (1) obvious anglicisms account for the most numerous group of anglicisms in the titles of professions; (2) raw anglicisms account for the least numerous group of anglicisms; (3) the share of anglicisms demonstrates a constant growth within the most popular categories of professions in the period observed in this paper. The presence of anglicisms in the titles of professions, on the one hand, implies that there are certain lexical gaps that need to be filled in so that the register of job titles can be completed, while, on the other hand, it demonstrates an alarmingly increasing number of anglicisms within the same register of the Serbian language.

Keywords: recent anglicisms, job titles, Internet advertisements, Serbian language

\section{JEL Classification: A12}

\section{INTRODUCTION}

Once the need for introducing new concepts, terms, and ideas has been identified in a language, the language starts importing words and phrases from a language it has been in direct or indirect contact with. When it comes to the Serbian language, it is influenced by the English as a "global language", especially in the

\footnotetext{
* Correspondence to: M. Milanovic, Faculty of Philology and Arts, University of Kragujevac, Jovana Cvijica b.b., 34000 Kragujevac, Serbia; e-mail: milan.milanovic@kg.ac.rs
}

area of business and economics, where this language exerts a recognisably large influence (Crystal, 2003) by introducing, even imposing, new or modified lexical contents into receiving languages, such as the Serbian language. It has recently been noted that there is a significant number of professions whose titles do not correspond to the names of qualifications obtained through formal education, as was not the case in the period preceding the transition in economy, when the job posts advertised in the media contained the titles aligned to the qualifications earned in secondary or higher education (e.g. a cook, a hair-dresser, a locksmith, 
a mechanical engineer, an economist, etc.). However, as some authors note, the process of privatizing public companies as well as the increasingly important role of international and transnational companies in the home market have affected both the changes in corporate culture and behaviour and changes occurring within the Serbian language under the influence of English (Dobrić, 2008a; Dobrić, 2008b; Novakov, 2008). The language of communication within a company and the language of business reportinghaveswitched from the Serbian in to the English language, and job posts are increasingly being published in English on specialized Internet portals and websites. Originally, advertisements were published in a foreign language only by international companies. However, this has changed, resulting in Serbian companies publishing ads in the English language, while, at the same time, they demand that applicants be able to demonstrate proficiency in both spoken and written English language. Often enough, ads are written both in the Serbian and the English languages;however, there is a tendency of taking job titles over from English, even when an advertisement is published in the Serbian language. Consequently, such job titles no longer correspond to those found in the formal education system of the Republic of Serbia. Taking certain titles of professions from English and using them in the Serbian language often implies that their form should undergo a process of adaptation and change so as to fit in better in the receiving language. Depending on the stage of their adaptation, or, in other words, depending on the time that has passed since they entered the Serbian language, the forms of such words are themselves a piece of evidence that they originate from the English language. Such words and phrases will be termed as anglicisms here, whereas those anglicisms which have been present in the Serbian language in the last 20 years we will refer to as recent anglicisms.

In this paper, we use a corpus analysis in order to identify recent anglicisms within the corpus of 60 professions most advertised between May, 2007 and the end of 2011, on the following web site: www.poslovi. infostud.com. The anglicisms we found there will be classified according to their form as raw, obvious, and hidden, in line with the typology proposed by Prćic (2005). The presence of anglicisms and their share in the corpus within the individual periods as well as within the overall period we observe will help us test the following hypotheses: (H1) obvious anglicisms will account for the most numerous subgroup of anglicisms as a result of a relatively fast process of job diversification in the circumstances of the transition economy; (H2) raw anglicisms will account for the least numerous subgroup of anglicisms, and their titles will imply that an equivalent and/or compact solution does not exist in Serbian; and (H3) the share of recent anglicisms in the overall distribution will mark a constant increase over the period we observe.

\section{RECENT ANGLICISMS IN JOB TITLES IN SERBIAN}

Filipović $(1986,193)$ maintains that the term anglicism refers to the words taken over from English, as a contributing language, by a receiving language where they are adapted according to the system of this language in which such words act as "native words". We draw the reader's attention to the fact that anglicisms are not only the characteristic of the Serbian language and the territory of the Republic of Serbia. On the contrary, this phenomenon has been noted at a larger scale, and it could evenbe a sign of linguistic colonialism (Filipović, 2009). According to this view, one can easily notice that countries in the neighbourhood, such as Croatia and Montenegro experience the same problem of frequent, often unjustified overuse of anglicisms (Lakić, 2008), which is closely related to the problems of their orthographic representation, their pronunciation, and often in translation (Antunović, 1996). Although some authors warn of the problem of adapting anglicisms to the systems of the Serbian and the Croatian languages, especially in terms of terminology standardization and avoiding linguistic ambiguities caused by the lack of standardization (Filipović, 1990; Silaški, 2009a, 2009b, 2009c), this issue has not been resolvedyet. This is especially true for business discourse ever since the economy of Serbia started the process of transition, as is observed by a number of authors dealing with anglicisms in the area of economics (Papović, 2000; Silaški, 2007).

In this paper, we focus on the words that already entered but also on those which are still entering the 
register of job titles in the Serbian language, with our purpose being that of discovering anglicisms that have emerged in the course of the last 10-15 years in the Serbian language. Such words will be termed as recent anglicisms (some of which may be found in (Vasić et al, 2001). Considering that what we focus on here is the register of job titles, which, in the circumstances of the transition economy, is prone to changes and modifications, older anglicisms, which do exist in Serbian language (e.g. direktor, sekretar, etc.), may be considered as sufficiently adapted to the system ofthe Serbian language that people no longer perceive them as words from a foreign language. Recent anglicisms, however, due to the short time having passed since they appeared in the Serbian language, do not get adapted that easily. Namely, it is fairly difficult to find equivalents in Serbian for the lexical content carried by such words; for this reason, they are often used in a form not taking into consideration the norms and standards of the Serbian language, which, in turn, may have long-term consequences on the morphological potential of the Serbian language to produce words of its own. As authors of this paper, wewould like to point to the alarmingly large number of anglicisms in job titles, but at the same time, we do not wish to take any extreme points of view, either linguistics puritanism or applauding to linguistic carelessness (Bugarski, 1996). Instead, we would like to underline the importance of cooperation and dialogue among employers, educational institutions, creators of language policies and linguists, who should undertake a joint venture of finding appropriate language solutions with the purpose of enriching as well as preserving the Serbian language.

\section{TYPOLOGY OF ANGLICISMS}

The way anglicisms areclassified is conditioned by the purpose of the authors conducting a research into them. In this paper, various types of recent anglicisms are considered in terms of their form, or in other words, in terms of their respective visual identities, which to a certain extent helps us identify them as words directly transferred from English into Serbian, or as the words modified so as to adapt to the system of the Serbian language, or finally as words difficult to recognize as foreign words, however actually reflecting the norm not of the Serbian but of the English language.

Drawing the reader's attention to the fact that there are various classifications possible to apply when taking about anglicisms (for example, anglicisms can be classified in accordance with the degree of their adaptation, as suggested by Filipović (1986) classifying them as primary and secondary anglicisms, i.e. as true anglicisms and pseudo-anglicisms), we underline that we are primarily interested in the formal realization of anglicisms withinthe morphological, phonological, and orthographic systems of the Serbian language, so for this reason we apply the typology of anglicisms proposed by Prćic (2005), classifying them as raw, obvious, and hidden. Raw anglicisms refer to words and phrases used in their original form, as they are found in the English language, without undergoing either primary or secondary adaptation in Filipovićs sense (1986). Besides, Prćić claims that, in an orthographic sense, such words are completely unadjusted to the system of the Serbian language, given the fact that they are only integrated at the level of semantics, and are only used in a limited set of circumstances. At the morphological and morphosintaxical levels, many anglicisms are used as they are in English, and for this reason they are seen as unadjusted to the system of the Serbian language. However, there are other words considered to be partially integrated because their pronunciation is adapted to the phonological system of the Serbian language, or in their pronunciation, speakers use some "English-Serbian mixture" (Prćić, $2005,121)$. An example of a raw anglicism not yet integrated at thephonological or orthographic level is an acronym found in the field of public relations, where a person who is in charge of them introduces himself or herself as a PR. Some other anglicisms (for example, the wordmerchandiser) are often partially integrated at the level of phonology, i.e. in pronunciation, due to differing quality consonants in Serbian and in English have. For this reason, this word is often heard being pronounced as/merčandajzer/, with a non-standardized and undetermined quality of the consonant $\mid \check{c} /$, which can be encountered as well as soft $/ \mathrm{t} \mathrm{J} /$, as it is found in the system of the English language. Obvious anglicisms are perceived as thenext step in adaptation, 
because they comprise lexical units (including affixes) which are taken over from the English language, but which quickly integrate within the system of the Serbian language, where, over time, they receive the status of a native word (e.g. direktor: Eng. director; menadžer: Eng. manager). The third type comprises words and phrases, which although conforming to the morphology of the Serbian language, reflect the usage and norms of the English language (Prćić, 2005, 121), and such anglicisms are termed as hidden, because the Serbian form of a word conceals its true identity. Hidden anglicisms are often made through the processes of translation (e.g. lični pomoćnik/-ica: Eng. personal assistant), reshaping (e.g. administrativni asistent: Eng. administrative assistant), but also by a combined method. i.e. translation and reshaping of the original word (e.g. asistent ljudskih resursa: Eng. human resources assistant). Taking into consideration the characteristics of raw, obvious, and hidden anglicisms, it can be assumed that raw anglicisms have recently appeared in the Serbian language. In the same way, it can be assumed that hidden anglicisms have gone the longest way in the process of adaptation, because they contain a lexical material preparedby using the morphological potentials of the Serbian language. When it comes to obvious anglicisms, however, it is not always possible to provide a reliable opinion on the time they have spent in the Serbian language, because it takes relatively little time for them to adapt and behave as native words within the receiving language. This is particularly the case with certain affixes speakers are exposed to, and for this reason, they adopt them easily (e.g. the suffix-er, as in menadžer), but this is also true for words and phrases without an adequate equivalent in the Serbian language (e.g. programer). A word's belonging to a certain type of anglicisms may indicate therelative age of the word or phrase that came from English into the Serbian language. In other words, if a certain raw anglicism appears as a job title within a given category of jobs, it may be assumed that it will soon start integrating within the receiving language, either as an obvious or hidden anglicism. Milanović (2011) illustrates this on the example of a job title found within the category of Trade. Namely, the word merchandiser (eng. merchandiser), is found to take the following forms in the corpus: merchandiser, merčandajzer, merčendajzer (including examples typed using the Cyrillic script: мерчендајзер and мерчандајзер), but also as Ser. pospešitelj prodaje. All forms of this word are identified as anglicisms; however, while thefirst one is identified as raw (i.e. merchandiser), the following two job titles can be identified as reshaped and adapted obvious anglicisms (merčandajzer, merčendajzer). Milanović (2012, 38) concluded that the latter represents a translated anglicism whose role is to fulfil a lexical gap in the Serbian language, occurring due to a lack of a Serbian word with the same meaning, while simultaneously being shaped in the form of the Serbian language, which makes it acceptable in the receiving language.

\section{CORPUS}

Given the fact that we intend to identify recent anglicisms in job titles published in advertisements online, we will analyze a corpus consisting of 39 job categories, within which we found 60 job titles (see Appendix for the full list of job titles found in the corpus; note, however, that recent anglicisms are typed in bold letters). All job titles are found in advertisements published on the Internet in the period from May, 2007 to the end of 2011. The corpus and the periods analyzed here were selected on the basis of the availability of data matching the purpose of our research. The data used in the paper are available at www.poslovi.infostud.com. They are related to the most popular job categories and professions sought by employers in the observed period, during which over 70,000 advertisements were published on this web page. The following job categories were found in the corpus: (1) administration and accounting; (2) architecture; (3) banking, finance; (4) biology; (5) beauty care; (6) design; (7) general economics (8) electrical engineering; (9) pharmacy; (10)physics; (11) graphic design; (12) construction engineering; (13) chemistry; (14) IT; (15) language, literature; (16) human resources; (17) marketing, PR; (18) mechanical engineering; (19) media, culture; (20) middle management, (21) higher management, consulting; (22) security; (23) education, child care; (24) insurance; (25) agriculture, forestry; (26) law; (27) food technology; (28) psychology; (29) traffic, logistics; (30) sociology; (31) technology, metallurgy; (32) telecommunications; (33) transportation, warehousing; 
(34) trade; (35) tourism, hospitality; (36) arts; (37) veterinarian medicine; (38) environment protection; (39) health care. The source provides information related to the share of thegiven category in the overall distribution per period, as well as the share of the respective professions in the overall distribution of sought-after jobs.

At this point, we find it worth making a distinction between the following three groups of job titles found in the corpus:

- Job titles published in Serbian corresponding to the names of qualifications earned in formal education (e.g. Ser. metaloglodač). Examples of the members of this group can be found in the following job titles: Ser. advokatski pripravnik, vatrogasac, zavarivač, etc.;

- Job titles generated under the influence of a foreign language (English, French, German, etc.), which have long been in use, as a result of which speakers of Serbian no longer consider them to be "foreign", because they have already become part of the norm in the Serbian language. As such, they have already found their place in the names of qualifications earned in formal education (e.g. Ser. diplomirani mašinski inženjer). Examples for the members of this group can be found in the following job titles: Ser.direktor, frizer, inženjer, etc. Given the fact that this group contains words originating from English as well, we will term such words as older anglicisms;

- The third and final group contains job titles which have been entering the Serbian language for the last 10-15 years, while their true origin is in the English language. These words have not conformed to the norms and standards of the Serbian language yet, and they are termed as recent anglicisms here. Some of these appear in job titles, i.e. qualifications earned in formal education (e.g. Ser.diplomiraniprogramer), but a number of these stay out of the system of qualifications. Examples for the members of this group can be found in the following job titles: Ser. HoReCa menadžer (and often HoReCa Manager), Ser. merčendajzer (but also merchandiser, merčandajzer, and even „мерчендајзер“), Ser. sistem inženjer (instead of inženjer informacionih sistema), etc.

It should be noted that a significant number of job advertisements are published in foreign languages, most often in English (although there are examples of ads published in the German, French, and Russian languages), especially when the employing company comes from abroad, or when this is an international company entering the Serbian market. However, there are two more tendencies observed with employers posting job advertisements on the Internet:

- companies advertise vacancies by posting a text typed in the Serbian language, in the Latin script, whereas the job title as well as the list of requirements expected of applicantsare provided in English, and

- he tendency contradicting the norms and orthography of the Serbian language when job posts are published in the Cyrillic script, while the job title itself is provided in English, using the Latin script.

\section{RESEARCH METHODOLOGY}

In this paper, we apply a corpus analysis in order to identify recent anglicisms, as well as to examine their share in the overall distribution of the most popular jobs during each of the observed periods. The analysis aims at finding examples of raw, obvious, and hidden anglicisms and their respective distributions within the following four periods observed here: Period 1 (May 2007 - December 2008), Period 2 (2009), Period 3 (2011) and Period 4 (2012). The criterion for observing a category in the list of 39 categories provided in the corpus is the minimal share of $1.5 \%$ in the overall distribution, which brings us to the number of 15 job categories to observe in the corpus (the last category will contain all those with ashare of less than 1.5\% in the overall distribution). In other words, to be considered relevant for the research, a category must be present with at least 300 job posts per year. The data we have obtained byanalyzing the 14 most popular job categories and the data we have obtained by analyzing 
recent anglicisms,being divided into three types, will help us test the following hypotheses:

- (H1): Obvious anglicisms will account for the most numerous subgroup of anglicisms as a result of therelatively fast process of job diversification in the circumstances of the transition economy.

- (H2): Raw anglicisms will account for the least numerous subgroup of anglicisms, and their titles will imply that an equivalent and/or compact solution does not exist in Serbian.

- (H3): The share of recent anglicisms in the overall distribution will mark a constant increase over the observed period.

\section{CORPUS ANALYSIS}

In this paper, we analyze the corpus in order to determine the type of anglicisms present there and their share in the overall distribution of the most advertised vacancies. The analysis includes 4 periods: Period 1 (May, 2007 - December, 2011), Period 2 (2009), Period 3 (2010), and Period 4 (2011).

\section{Period 1}

The earliest data made available by our source are those of the period between May, 2007 andthe end of 2008, during which over 20,000 job advertisements were published on the following web site:www. poslovi.infostud.com (Infostud, 2009). In this period, the most popular jobs with employers were the jobs within the following 15 categories (Graph 1): (1) trade (16.23\%); (2) administration, accounting (10.89\%), (3) general economics (10.28); (4) middle management (6.63); (5) IT (6.32\%); (6) construction engineering (4.14\%); (7) mechanical engineering (3.99\%); (8) electrical engineering (3.94\%); (9) transportation, warehousing (3.55\%); (10) marketing, PR (3.54\%); (11) tourism, hospitality (3.19\%); (12) banking, finance (2.58\%); (13) pharmacy $(1.78 \%) ;(14)$ higher management, consulting $(1.71 \%)$; $(15)$ other $(21.23 \%)$.

The most popular professions within these 14 categories (category 15 contains all the categories whose share in

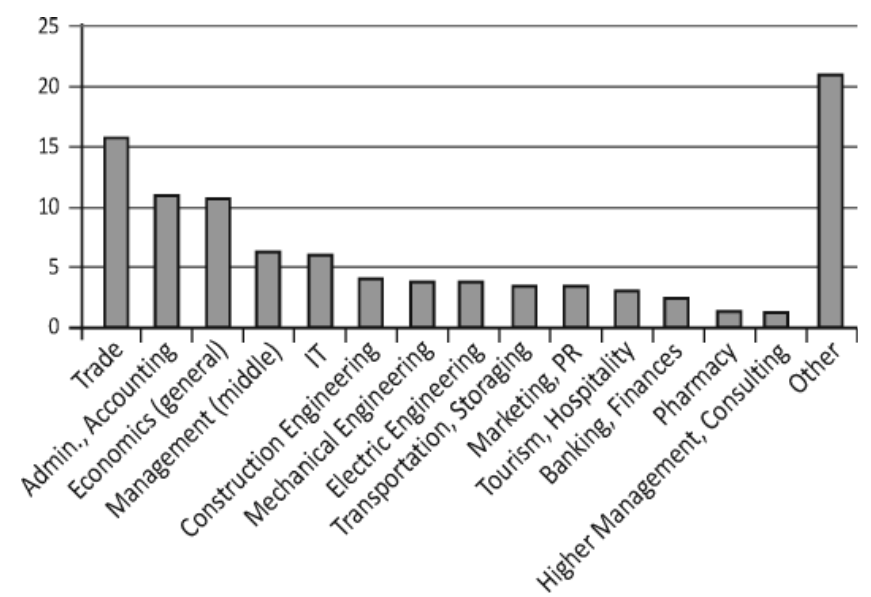

Graph 1 The structure of the most popular professions in the period between May, 2007 and the end of December 2008

Izvor: Authors, based on Infostud, 2009

the overall distribution is less than $1.5 \%$ ) (Numbers correspond to the job category in which the job titles are found): (1) komercijalista (Eng. commercial representative), prodavac (Eng. office assistant); (2) knjigovođa (Eng. book-keeper), poslovni sekretar (Eng. business secretary); (3) knjigovođa (certain job titles appear more than once in the corpus, but they are considered as a single job title), menadžer prodaje (Eng. sales manager); (4) menadžer prodaje; (5) programer (Eng. programmer), sistem inženjer (Eng. system engineer).; (6) građevinski inženjer (Eng. construction engineer); (7) mašinski inženjer (Eng. mechanical engineering), (8) diplomirani inženjer elektrotehnike (Eng. electric engineer), (9) vozač (Eng. driver), magacioner (Eng. warehouse keeper); (10) saradnik u marketing (Eng. marketing officer), promoter (Eng. promoter); (11) konobar (Eng. waiter), kuvar; (12) saradnik (Eng. associate), kreditni službenik (Eng. loan officer); (13) diplomirani farmaceut (Eng. pharmacist), medicinski predstavnik (Eng. medical representative), farmaceutski tehničar(Eng. pharmaceutical technician); (14) komercijalni direktor (Eng. commercial manager), HR manager (Eng. HR manager), (15) other (Infostud, 2009). 


\section{Period 2}

In this period, employers were mostly interested in candidates possessing qualifications related to the following job categories (Graph 2): (1) trade (18.63\%); (2) middle management (11.44\%), (3) general economics (9.75\%); (4) administration, accounting (9.18\%); (5) IT (5.60\%); (6) banking, finance (3.94\%); (7) marketing, PR (3.59\%); (8) tourism, hospitality (3.25\%); (9) mechanical engineering (3.07\%); (10) electrical engineering $(2.90 \%)$; (11) pharmacy (2.89\%); (12) higher management, consulting $(2.26 \%)$; (13) transportation, warehousing (2.22\%); (14) medicine (1.71\%); (15) other (19.16\%).

By using a corpus analysis, we identified the following job categories as those which were the most popular ones with employers in 2009: (1) komercijalista, prodavac; (2) menadžer prodaje, poslovođa (Eng. senior manager); (3) računovođa, direktor prodaje; (4) poslovni sekretar, knjigovođa, telefonski operater (Eng. call center operater); (5) programer, PHP developer (Eng. PHP developer); (6) kreditni službenik, blagajnik (Eng. cashier), finansijski analitičar (Eng. financial analyst); (7) marketing menadžer (Eng. marketing manager), promoter, brendmenadžer (Eng. brand manager); (8) konobar, kuvar (Eng. chef); (9) mašinski inženjer, bravar; (10) serviser, električar; (11) stručni saradnik u farmaciji (Eng. pharmaceutical representative), diplomirani farmaceut; (12) generalni direktor, izvršni direktor; (13) magacioner, vozač; (14) lekar, stručni saradnik u medicini; (15) other (Infostud, 2010).

\section{Period 3}

In the period between January and December 2009, employers were mostly interested in the following job categories (Graph 3): (1) trade (17.90\%); (2) middle management (10.87\%); (3) general economics $(10.26 \%)$; (4) administration, accounting (8.06\%); (5) IT (6.17\%); (6) banking, finance (4.04\%); (7) electrical engineering (3.71\%); (8) marketing, PR (3.56\%); (9) mechanical engineering (3.38\%); (10) tourism, hospitality $(3.17 \%)$; (11) higher management, consulting (2.84\%); (12) transportation, warehousing (2.29\%); (13) pharmacy $(2.27 \%)$; (14) construction engineering (1.95\%); (15) other $(13.37 \%)$.

In 2010, the most popular professions found within the 14 most popular categories are as follows: (1) komercijalista, merchandiser (Eng. merchandiser), prodavac; (2) menadžer prodaje i izvoza (Eng. sales and exports manager), poslovođa; (3) diplomirani ekonomista, finansijski direktor; (4) administrativni

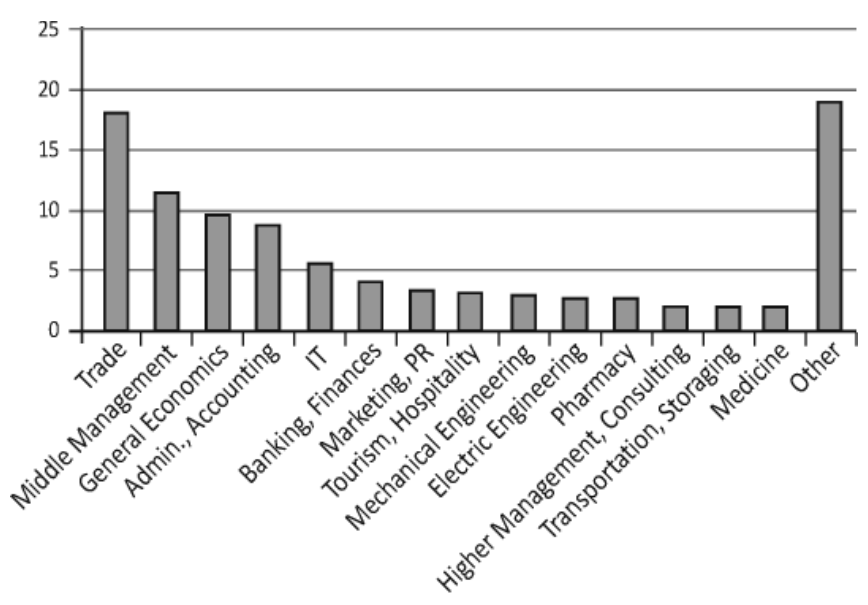

Graph 2 The structure of the most popular professions in 2009

Izvor: Authors, based on Infostud, 2010

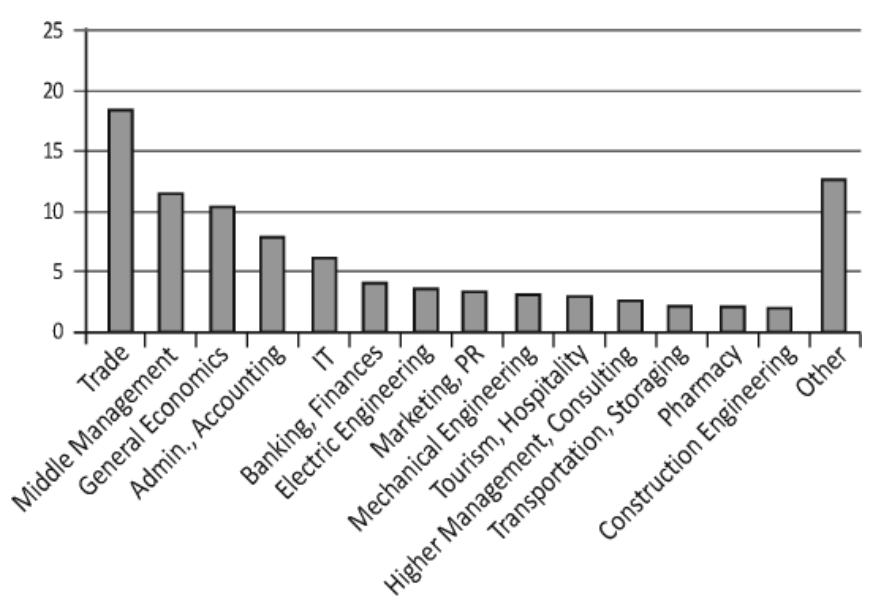

Graph 3 The structure of the most popular professions in 2010

Izvor: Authors, based on Infostud, 2011 
radnik (Eng. administrative officer), poslovni sekretar, knjigovođa; (5) administrator baza podataka (Eng. data base administrator), programer, web dizajner (Eng. web designer); (6) bankarski službenik; (7) serviser, električar; (8) marketing menadžer, promoter, brend menadžer (Eng. brand manager); (9) mašinski inženjer; (10) menadžer ugostiteljstva (Eng. hospitality manager), konobar, kuvar; (11) menadžer projekta (Eng. project manager), direktor; (12) magacioner, vozač; (13) diplomirani farmaceut; (14) diplomirani građevinski inženjer, građevinski tehničar (Eng. construction officer), građevinski projektant (Eng. construction project engineer); (15) other (Infostud, 2011).

\section{Period 4}

In 2011, employers were largely interested in the following job categories (Graph 4): (1) trade (16.66\%); (2) middle management $(10.84 \%)$, (3) general economics $(9.22 \%)$; (4) administration, accounting (7.94\%); (5) electrical engineering (4.77\%); (6) mechanical engineering (3.98\%); (7) banking, finance $(3.55 \%) ;(8)$ marketing, PR (3.05\%); (9) tourism, hospitality (2.69\%); (10) construction engineering (2.39\%); (11) higher management, consulting (2.27\%); (12) transportation, warehousing (2.26\%); (13) law (1.86\%); (14) pharmacy $(1.75 \%)$; (15) other $(13.37 \%)$.

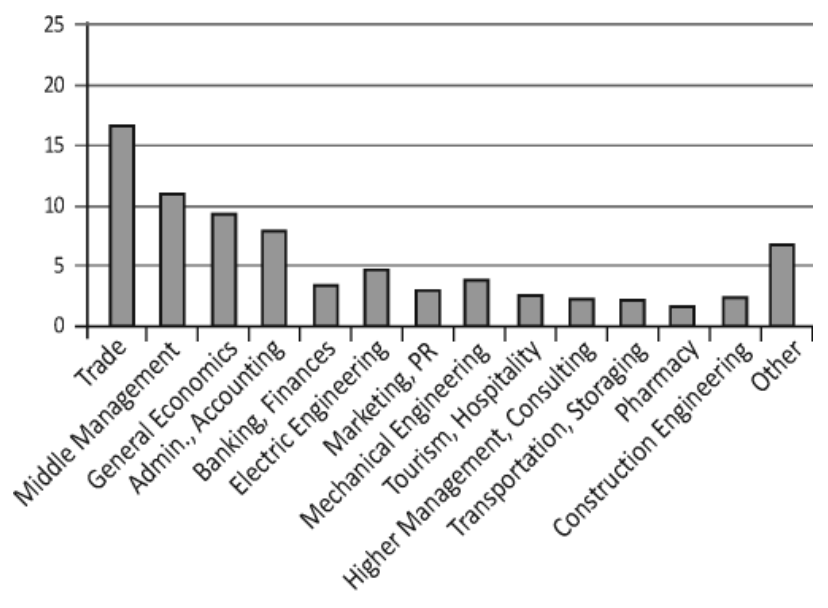

Graph 4 The structure of the most popular professions in 2011

Izvor: Authors, based on Infostud, 2012
In 2011, the most popular professions found within the 14 most popular categories are the following ones: (1) HoReCa menadžer (Eng. HoReCa manager), merchandiser, prodavac; (2) menadžer prodaje i izvoza; (3) diplomirani ekonomista; (4) administrativni radnik, poslovni sekretar, telefonski operater; (5) serviser, električar; (6) mašinski inženjer; (7) blagajnik; (8) marketing istraživač (Eng. marketing researcher), PR menadžer (Eng. PR manager), PR (Eng. PR), brendmenadžer; (9) menadžer ugostiteljstva, glavnikuvar, kuvar; (10) diplomirani građevinski inženjer, građevinski projektant; (11) direktor; (12) kurir (Eng. courier), magacioner, vozač; (13) diplomirani pravnik; (14) diplomirani farmaceut; (15) other (Infostud, 2012).

\section{CORPUS ANALYSIS: TYPES OF ANGLICISMS AND THEIR SHARE IN THE DISTRIBUTION OF THE MOST POPULAR PROFESSIONS}

Period 1: Having analyzed the corpus, we conclude that there are 23 job titles found inthe list of 14 most popular job categories advertised in the period between May 2007 and December 2008. Relying on the adopted typology of anglicisms, and in line with the research methodology of our choice, it has been established that, based on their form, 9 job titles can be identified as anglicisms. Dividing them into different types, based on their form as well, we found that there are examples of obvious, hidden, and raw anglicisms in the corpus. Obvious anglicisms are: komercijalista,programer, promoter and sistem inženjer. Hidden anglicisms are: kreditni službenik, medicinski predstavnik, menadžer prodaje, poslovnisekretar, whereas there is only one raw anglicism: HR manager (Table 1). Judging by the number of the anglicisms found in this period, it can be concluded that they account for $39.13 \%$ of all job titles found in thissubcorpus.

Period 2: In the following period, namely, in 2009, the overall number of job titles found in the corpus is somewhat higher than in Period 1, since there are 31 job titles found in Period 2. Among all job titles found in this subcorpus, we identified 11 anglicisms out of which obvious, hidden, and raw anglicisms have all been identified. Obvious anglicisms are: komercijalista, 
Table 1 Types of recent anglicisms in the names of the most popular professions per period

\begin{tabular}{|c|c|c|c|c|}
\hline & Period 1 & Period 2 & Period 3 & Period 4 \\
\hline Obvious anglicisms & $\begin{array}{l}\text { komercijalista, programer, } \\
\text { promoter, sistem inženjer }\end{array}$ & $\begin{array}{l}\text { komercijalista, program- } \\
\text { er, finansijski analitičar, } \\
\text { marketing menadžer, } \\
\text { promoter, brend } \\
\text { menadžer }\end{array}$ & $\begin{array}{l}\text { komercijalista, admin- } \\
\text { istrator baza podataka, } \\
\text { programer, web dizajner, } \\
\text { marketing menadžer, } \\
\text { brend menadžer, } \\
\text { menadžer projekta }\end{array}$ & $\begin{array}{l}\text { HoReCa menadžer, } \\
\text { PR menadžer, brend } \\
\text { menadžer }\end{array}$ \\
\hline Hidden anglicisms & $\begin{array}{l}\text { kreditni službenik, } \\
\text { medicinski predstavnik, } \\
\text { menadžer prodaje, } \\
\text { poslovni sekretar, }\end{array}$ & $\begin{array}{l}\text { kreditni službenik, } \\
\text { menadžer prodaje, } \\
\text { poslovni sekretar, tele- } \\
\text { fonski operater }\end{array}$ & $\begin{array}{l}\text { administrativni radnik, } \\
\text { menadžer prodaje i } \\
\text { izvoza, poslovni sekretar, } \\
\text { menadžer ugostiteljstva, } \\
\text { građevinski projektant }\end{array}$ & $\begin{array}{l}\text { menadžer prodaje i izvoza, } \\
\text { administrativni radnik, } \\
\text { poslovni sekretar, tele- } \\
\text { fonski operater, market- } \\
\text { ing istraživač, menadžer } \\
\text { ugostiteljstva, građevinski } \\
\text { projektant }\end{array}$ \\
\hline Raw anglicisms & HR manager & PHP developer & merchandiser & merchandiser, PR \\
\hline $\begin{array}{l}\text { Share in total distri- } \\
\text { bution }\end{array}$ & $39.13 \%$ & $35.48 \%$ & $46.66 \%$ & $44.44 \%$ \\
\hline
\end{tabular}

programer, finansijski analitičar, marketing menadžer, promoter, brend menadžer. The following belong to the group of hidden anglicisms: kreditni službenik, menadžer prodaje, poslovni sekretar, telefonski operater. The following raw anglicism was found within the category of Information technologies: PHP developer (Table 1). Based on the number of anglicisms found in the subcorpus, it can be concluded that their share in the overall distribution of job titles is $35.48 \%$.

Period 3: In the year 2010, the number of the most popular job titles is by one lower than in 2009, resulting in 30 job titles found in the subcorpus, out of which there are 14 anglicisms. The analysis of this subcorpus shows evidence of obvious, hidden, and raw anglicisms in the job titles of this group. Obvious anglicisms are as follows: komercijalista, administrator baza podataka, programer, web dizajner, marketing menadžer, brend menadžer, menadžer projekta. The following are identified as hidden anglicisms: administrativni radnik, menadžer prodaje i izvoza, poslovni sekretar, menadžer ugostiteljstva, građevinski projektant. There is also one raw anglicism identified within the subcorpus: merchandiser (Table 1). Based on the number of anglicisms found in the subcorpus, it can be concluded that their share in the overall distribution of job titles is $46.66 \%$.
Period 4: In 2011, which is the final period analysedin this paper, the number of anglicisms found is lower than in the previous year since there are only 27 job titles found in advertisements. The analysis of these job titles helped us identify 12 anglicisms, among which there are examples of obvious, hidden, and raw anglicisms. Obvious anglicisms are: HoReCa menadžer, PR menadžer, and brend menadžer. Hidden anglicisms are the following ones: menadžer prodaje i izvoza, administrativni radnik, poslovni sekretar, telefonski operater, marketing istraživač, menadžer ugostiteljstva, građevinski projektant. Two raw anglicisms have been identified in the subcorpus. One of them is merchandiser, whereas the other is $\mathrm{PR}$, which appearsin the corpus of the most popular professions in 2011 (Table 1). Based on the number of the anglicisms found in the subcorpus, it can be concluded that their share in the overall distribution of job titles is $44.44 \%$.

\section{THE ANALYSIS OF THE FINDINGS}

There is a total of 60 job titles we have analyzed within the 14 most popular job categories, covering the period from May, 2007 tothe end of 2011. As a result, we 
identified 26 job titles whose form represents this or that type of anglicisms, meaning that $43.33 \%$ of all job titles are obvious, hidden, or raw anglicisms.

Table 2 shows the raw, obvious, and hidden anglicisms identified in the corpus:

Table 2: Types and share of anglicisms in the corpus

\begin{tabular}{|c|c|c|c|}
\hline $\begin{array}{l}\text { Type of angli- } \\
\text { cisms: }\end{array}$ & $\begin{array}{l}\text { Raw angli- } \\
\text { cisms }\end{array}$ & $\begin{array}{l}\text { Obvious } \\
\text { anglicisms }\end{array}$ & $\begin{array}{l}\text { Hidden angli- } \\
\text { cisms }\end{array}$ \\
\hline Anglicisms & $\begin{array}{l}\text { HR manager, } \\
\text { merchan- } \\
\text { diser, PHP } \\
\text { developer, } \\
\text { PR }\end{array}$ & $\begin{array}{l}\text { administrator } \\
\text { baza poda- } \\
\text { taka, brend } \\
\text { menadžer, } \\
\text { finansi- } \\
\text { jski analitičar, } \\
\text { HoReCa } \\
\text { menadžer, } \\
\text { komercijalis- } \\
\text { ta, marketing } \\
\text { menadžer, } \\
\text { menadžer } \\
\text { projekta, PR } \\
\text { menadžer, } \\
\text { programer, } \\
\text { promoter, } \\
\text { sistem } \\
\text { inženjer, web } \\
\text { dizajner }\end{array}$ & $\begin{array}{l}\text { administra- } \\
\text { tivni radnik, } \\
\text { građevinski } \\
\text { projektant, } \\
\text { kreditni } \\
\text { službenik, } \\
\text { marketing } \\
\text { istraživač, } \\
\text { medicinski } \\
\text { predstavnik, } \\
\text { menadžer } \\
\text { prodaje, } \\
\text { menadžer } \\
\text { prodaje } \\
\text { i izvoza, } \\
\text { menadžer } \\
\text { ugostiteljst- } \\
\text { va, poslovni } \\
\text { sekretar, } \\
\text { telefonski } \\
\text { operater }\end{array}$ \\
\hline $\begin{array}{l}\text { The number } \\
\text { of anglicisms } \\
\text { found in the } \\
\text { corpus }\end{array}$ & 4 & 12 & 10 \\
\hline $\begin{array}{l}\text { Share of an- } \\
\text { glicisms in \% }\end{array}$ & 15.38 & 46,15 & 38,47 \\
\hline
\end{tabular}

Considering the fact that our analysis of the corpus shows evidence of anglicisms in it, below we analyze the findings with respect to our hypotheses set at the beginning of this paper:

H1: Obvious anglicisms will account for the most numerous subgroup of anglicisms as a result of therelatively fast process of job diversification in the circumstances of the transition economy.

Having found 12 obvious, 10 hidden, and 4 raw anglicisms in the total of 26 , we conclude that this hypothesis is confirmed since the share of obvious anglicisms in the total number of anglicisms is $46.15 \%$.

In the circumstances of the transition economy, privatized and foreign companies emerging on the markets in Serbia "dictate" changes at all levels of corporate culture and behaviour, including changes in the descriptions of jobs that people take with such companies. However, the qualifications earned in the formal system of education in the Republic of Serbia do not always correspond to the job titles found in these groups, and for this reason such job titles cannot be regarded as Serbian, although they do conform to the phonological and orthographic system of the Serbian language. Considering the fact that obvious anglicisms are found in this corpus, we can make the following deductions:

- There is a considerable interest on behalf of employers for such professions, with a repetitive interest occurring in the case of some professions (e.g. komercijalista, brend menadžer, marketing menadžer, etc.).

- Some of the job titles in this group reflect a need to fulfillthe lexical gaps existing in the Serbian language (e.g. programer), whereas the others reflect carelessness in using anglicisms instead of the Serbian equivalents (e.g. upravnik or rukovodilac instead of menadžer).

H2: Raw anglicisms will account for the least numerous subgroup of anglicisms, and their titles will imply that an equivalent and/or compact solution does not exist in Serbian.

There are the following raw anglicisms found in the corpus: HR manager, merchandiser, PHP developer, PR. If we take into consideration the fact that the number of raw anglicisms is 4 , it can be concluded that they account for $15.38 \%$ of all the identified anglicisms in the corpus. This consequently confirms H2. 
Raw anglicisms can be found in relatively recent job titles for which there are still no adequate solutions in the Serbian language. Some of these anglicisms, if frequently used, can be found in their intermediate, adapted forms, as indicated by the example of merchandiser in Milanović (2011). It is assumed by H2 that raw anglicisms are found onsuch occasions when the Serbian language does not offer lexical solutions for a given term in the English language, or even if it does, the solution is insufficiently compact, so that users opt for more concise solutions for the sake of linguistic economy. This can be illustrated by an example found in the category of IT: PHP developer. Although the termdenotes a person involved in developing PHP applications, there is no equivalent in Serbian to be sufficiently concise to express the same meaning as in English.

H3: The share of recent anglicisms in the overall distribution will mark a constant increase over the period we observe.

During the first and the third period, the share of anglicisms is higher than in the remaining two periods, their share being $39.13 \%$ and $46.66 \%$ in Period 1 and Period 2, respectively. In the second, as well as in the fourth period, the share of anglicisms decreases in relation to the preceding periods, since they account for $35.48 \%$ of total job titles in Period 2, and $44.44 \%$ in Period 4. Based on these results, it can be concluded that $\mathrm{H} 3$ is rejected, since the share of anglicisms does not display a constant growth over periods. Instead, it can be concluded that the periods of growth are succeeded by the periods of decline. Based on the data illustrated in Table 1, certain professions can be assumed to be losing popularity over time, because of which they are no longer present in the subcorpus of the following period. For example, job titles such as sistem inženjer, HR manager, medicinski predstavnik are included in the list of the most popular professions in Period 1, after which they leave the corpus, whereas some other job titles such as telefonski operater display a tendency of cyclic reoccurring over time (Period 2 and Period 4). By this, it can be concluded that once the market has become saturated with certain professions, they lose appeal with employers.
If we analyze the above-mentioned findings from the perspective of the national language policy, it can be concluded that the number of anglicisms in this register is (alarmingly) increasing. During the first two periods, anglicisms account for about $30 \%$ of all job titles in the corpus. In the two periods following them, this number increases, amounting to and even exceeding $40 \%$. A conclusion can be made that such a sudden increase in the use of anglicisms may have an adverse effect on the usage of the morphological potentials of the Serbian language. Otherwise, one can only deduce that the Serbian language does not possess linguistic resources to fill in lexical gaps in the register of job titles. Some authors warn about the frequently unjustified use of anglicisms in job titles (Milanović 2011; Milanović \& Milanović, 2012a; Milanović \& Milanović, 2012b), suggesting that equivalent solutions may also be found by using the potentials of the Serbian language.

\section{CONCLUSION}

In this paper, we analyzed the corpus consisting of the job titles advertised on the Internet, with the purpose of identifying and classifying recent anglicisms in the names of the most popular professions in the period between May, 2007 and the end of 2011. Assuming that economic trends affect all spheres of life, we wanted to examine the extent to which the linguistic globalization and omnipresence of the English language affectsthe language solutions in the register of job titles in the Serbian language. This issue is closely related to the existence and application of a national language policy aimed at the preservation as well as enrichment of the Serbian language. In this paper, we tested three hypotheses. The first hypothesis related to the assumption that anumber of obvious anglicisms will account for the largest number of anglicisms found in the corpus was confirmed because we identified 12 obvious, 10 hidden, and 4 raw anglicisms in the corpus of 60 job titles. Based on such a high number of obvious anglicisms $(46.15 \%)$, we can draw a conclusion that these professions have been present onthe labour market for a longer time than those found within the other two groups of anglicisms. Furthermore, 
it can be deduced that there is a real need to devise adequate language solutions in Serbian for them. In their absence, these words display an adapted form (at the morphophonological level) of recent anglicisms used so as to fill in the lexical gaps in the Serbian language. However, despite the partial justifiability of their use, it can be noted that in many cases the potentials of the Serbian language are overseen in the circumstances of "anglocoolture" as Prćić calls it (2005). The second hypothesis, assuming that raw anglicisms will account for the smallest proportion in the overall distribution, was also confirmed, given the fact that only 4 anglicisms were identified to belong to this group. Their presence witnesses that there is a lack of lexical means to transfer lexical contents easily from English into the Serbian language. Given that raw anglicisms are of late, it can be assumed that, in the adaptation stages to follow, these will become adjusted and become obvious and/or hidden anglicisms, provided no other solution has been found by that time. The third hypothesis assuming that the share of anglicisms will mark a constant growth throughout the periods observed was rejected after the analysis had beenperformed. Instead of aconstant growth, we observed a fluctuation marked by a slight fall from $39.13 \%$ to $35.48 \%$ in Period 2, which was followed by a slight rise to $46.66 \%$ in Period 3, and finally a slight fall to $44.44 \%$ in the Period 4 . However, regardless of the fact that there is no constant growth in the share of anglicisms within the overall distribution, it can be noted that the share of anglicisms increases at the level of the total period, because it exceeds $40 \%$ in Periods 3 and 4.

At the end of this paper, we would like to say that we are aware of some of its limitations as well as of the need for conducting a further research that may be motivated by this one. Namely, we used data made available by our main source, based on the tens of thousands of the advertisements published in the period which there are available data for (May, 2007 - December 2011). It is possible, however, that a large-scale corpus analysis encompassing the texts of all the published advertisements may result in more comprehensive findings, particularly in terms of the intermediate forms of anglicisms (as is the case with the word merchandiser, discovered in Milanović
(2011)). Apart from that, the data we processed here could be analyzed from the perspective of disciplines other than contact linguistics and sociolinguistics, for example, from the perspective of economics, language planning, etc. Finally, we would like to underline the fact that one of the main reasons for conducting this research and sharing results based on it is our wish to inspire a dialogue between employers providing a number of job titles and linguists who may help them do that in order to enrich and preserve the Serbian language.

\section{REFERENCES}

Antunović, G. (1996). Anglicizmi i prevođenje: bez konzultinga nema happy enda. U M. Ž. Fuchs (Ur.), Suvremena lingvistika, $\mathrm{I}-2,(1-9)$.

Bugarski, R. (1996). Uvod u opštu lingvistiku. Beograd: Čigoja štampa.

Crystal, D. (2003). English as a global language. Cambridge: Cambridge University Press.

Dobrić, N. (2008a). Nazivi novih poslova - menadžeri. Škola biznisa II. Beograd: Visoka poslovna škola strukovnih studija.

Dobrić, N. (2008b). Uticaj engleskog na nazive poslova. U Mišić-Ilić, Lopičić (Ur.), Language, literature and globalization, (305-316).

Filipović, R. (1986). Teorija jezika u kontaktu: Uvod u lingvistiku jezičnih dodira. Zagreb: Školska knjiga.

Filipović, R. (1990). Anglicizmi u hrvatskom ili srpskom jeziku: Porijeklo, Razvoj-Značenje. Zagreb: Jugoslavenska akademija znanosti i umjetnosti - Školska knjiga.

Filipović, J. (2009). Moć reči. Beograd: Zadužbina Andrejević

Infostud. (2009). Tražena zanimanja u 2008. godini. Retrieved August 22, 2012 from Poslovi Infostud: http://poslovi. infostud.com/info/trazena-zanimanja/

Infostud. (2010). Tražena zanimanja u 2009. godini. Retrieved August 23, 2012 from Poslovi Infostud: http://poslovi. infostud.com/info/trazena-zanimanja/

Infostud. (2011). Tražena zanimanja u 2010. godini. Retrieved August 23, 2012 from Poslovi Infostud: http://poslovi. infostud.com/info/trazena-zanimanja/ 
Infostud. (2012). Struktura traženih zanimanja u 2011. godini. Retrieved August 23, 2012 from Poslovi Infostud: http:// poslovi.infostud.com/info/trazena-zanimanja/

Lakić, I. (2008). Anglicizmi u crnogorskom jeziku. U: Zbornik sa međunarodnog naučnog skupa „Njegoševi dani“, (321-328). Cetinje: Institut za jezik i književnost Filozofskog fakulteta

Milanović, A. (2011). Anglicizmi u nazivima zanimanja u srpskom jeziku. Neobjavljena master teza, Univerzitet u Beogradu, Filološki fakultet.

Milanović, A., \& Milanović, M. (2012a). Analiza anglicizama u nazivima zanimanja $u$ oblastima poslovne administracije i trgovine. Srpski jezik, XVII(1-2), 441-461.

Milanović, A., \& Milanović, M. (2012b). Pregled i analiza anglicizama $\mathrm{u}$ nazivima novijih zanimanja u poslovnim oglasima objavljenim na internetu. Lipar, 48, 187-201.

Novakov, P. (2008). Anglicisms in business Serbian-a linguistic and cultural transfer. In K. Rasulić, \& I. Trbojević-Milošević (Eds.), ELLSSAC Proceedings, I. (447-456). University of Belgrade, Faculty of Philology.

Papović, N. (2000). Anglicizmi u poslovnom životu. U M. Bjeletić, \& M. Vučinić (Ur.), Zbornik radova Beogradske otvorene škole, II-2 (161 - 177). Beograd: Beogradska otvorena škola.
Prćić, T. (2005). Engleski u srpskom. Novi Sad: Zmaj.

Silaški, N. (2007). Language in transition - of mergers, leverages and customisations. In B. Rakita, S. Lovreta, M. Petković(Eds.), Marketing and Management under Globalization. Proceedings of the International Scientific Conference Contemporary Challenges of Theory and Practice in Economics (361-371). Belgrade: Faculty of Economics of the University of Belgrade - Publishing Centre.

Silaški, N. (2009a). Anglicisms in Serbian business and economics discourse - is it zajedničko ulaganje, džoint venčer or joint venture?, U I. Lakić, N. Kostić (Ur.), Jezici i kulture u kontaktu - Zbornik radova (361-371). Podgorica: Institut za strane jezike.

Silaški, N. (2009b). Economic terminology in Serbian and Croatian - a comparative analysis of anglicisms. Facta Universitatis, Series: Linguistics and Literature, 7(1), (75-86).

Silaški, N. (2009c). Ka standardizaciji terminologije u oblasti marketinga i menadžmenta. Ekonomske teme, XLVII/3, (111125).

Vasić, V., Prćić, T., Nejgebauer, G. (2001). Du yu speak anglosrpski? Rečnik novijih anglicizama, Novi Sad: Zmaj 


\section{APENDIX \\ The most popular professions advertized \\ (Recent anglicisms are printed in bold)}

administrativni radnik
administrator baza podataka
bankarski službenik
blagajnik
bravar
brend menadžer
diplomirani ekonomista
diplomirani farmaceut
diplomirani građevinski
inženjer
diplomirani inženjer elek-
trotehnike
diplomirani pravnik
direktor
direktor prodaje
električar

administrativni radnik

bankarski službenik

farmaceutski tehničar

finansijski analitičar

finansijski direktor

generalni direktor

glavni kuvar

građevinski inženjer

građevinski projektant

građevinski tehničar

HoReCa menadžer

HR manager

izvršni direktor

knjigovođa

komercijalista

komercijalni direktor

konobar

kreditni službenik

kurir
kuvar
lekar
magacioner
marketing istraživač
marketing menadžer
mašinski inženjer
medicinski predstavnik
menadžer prodaje
menadžer prodaje i izvoza
menadžer projekta
menadžer ugostiteljstva
merchandiser
PHP developer
poslovni sekretar
poslovođa

PR

PR menadžer

prodavac

programer

promoter

računovođa

saradnik

saradnik u marketingu

serviser

sistem inženjer

stručni saradnik u farmaciji

telefonski operater

vozač

web dizajner
Received on $19^{\text {th }}$ October 2012, after one revision, accepted for publication on $12^{\text {th }}$ December 2012

Milan Milanovic is a PhD candidate at the Faculty of Philology, University of Belgrade. Since 2003, he has been employed with the English Department of the Faculty of Philology and Arts, University of Kragujevac. His interests include the following: testing, assessment, ESP, translation and interpreting.

Ana Milanovic is a PhD candidate at the Faculty of Philology, University of Belgrade. Her fields of interest include the following: contact linguistics, foreign language assessment, semantics, lexicology, translation. 


\title{
KOJIM JEZIKOM GOVORE POSLODAVCI? O PRISUSTVU NOVIJIH ANGLICIZAMA U NAZIVIMA NAJTRAŽENIJIH ZANIMANJA OGLAŠENIH PUTEM INTERNETA
}

\author{
Milan D. Milanović, ${ }^{*}$ Ana D. Milanović \\ Filološko-umetnički fakultet Univerziteta u Kragujevcu
}

U radu se analiziraju nazivi najtraženijih zanimanja u poslovnim oglasima objavljenim putem interneta kako bi se među njima identifikovali oni nazivi koji po svom obliku predstavljaju neku vrstu novijih anglicizama. Klasifikacija anglicizama vrši se prema podeli na vrste koju predlaže Prćić (2005), deleći anglicizme na osnovu njihove obličke realizacije na sirove, očigledne, i skrivene, čime se ukazuje na stepen njihove adaptacije u okviru srpskog jezika. Putem analize korpusa proverava se tačnost postavljenih hipoteza: (1) očigledni anglicizmi predstavljaju najbrojniju grupu anglicizama u korpusu najtraženijih zanimanja; (2) sirovi anglicizmi predstavljaju najmalobrojniju grupu anglicizama; i (3) učešće novijih anglicizama beleži tendenciju konstantnog rasta $\mathrm{u}$ kategorijama najtraženijih radnih mesta tokom posmatranog perioda. Prisustvo anglicizama $\mathrm{u}$ nazivima zanimanja, $\mathrm{s}$ jedne strane, ukazuje na određene leksičke praznine $\mathrm{u}$ srpskom jeziku koje treba popuniti kako bi se iskazao sadržaj za kojim postoji potreba u registru naziva zanimanja, dok, s druge strane, ukazuje na zabrinjavajuće veliki porast broja anglicizama u ovom reguistru srpskog jezika.

Ključne reči: noviji anglicizmi, nazivi zanimanja, internet oglasi, srpski jezik

\section{JEL Classification: A12}

\section{UVOD}

Kada se u jednom jeziku javi potreba za novim rečima, sa ciljem imenovanja novih predmeta, pojmova ili ideja, dolazi do preuzimanja reči ili celih izraza iz stranog jezika sa kojim je dati jezik u posrednom ili neposrednom kontaktu. U slučaju srpskog jezika, $u$ sferi poslovanja dešavaju se jezički kontakti u kojima

\footnotetext{
* Korespondencija: M. Milanović, Filološko-umetnički fakultet Univerziteta u Kragujevcu, Jovana Cvijića b.b., 34000 Kragujevac, Srbija;

e-mail: milan.milanovic@kg.ac.rs
}

engleski, kao „globalni jezik“ (Crystal, 2003), utiče na govornu i pisanu praksu govornika srpskog jezika putem unošenja, pa i nametanja, novog ili izmenjenog leksičkog sadržaja za kojim postoji manja ili veća potreba. Poslednjih godina je uočena pojava određenih zanimanja čiji nazivi ne korespondiraju sa nazivima kvalifikacija stečenih tokom formalnog obrazovanja, za razliku od perioda koji je prethodio procesu ekonomske tranzicije kada su upražnjena radna mesta koja su poslodavci oglašavali putem javnih glasila $u$ svom nazivu sadržala zvanje stečeno tokom srednjeg ili visokog obrazovanja (na primer: kuvar, frizer, bravar, 
diplomiranimašinski inženjer, diplomiraniekonomista, itd.). Međutim, kao što pojedini autori primećuju privatizacija javnih preduzeća kao i ulazak inostranih i transnacionalnih kompanija na srpsko tržište sa sobom donose ne samo promene $u$ poslovnom ponašanju i korporativnoj kulturi, već i promene na lingvističkom planu koje nastaju pod uticajem engleskog jezika (Dobrić, 2008a; Dobrić, 2008b; Novakov, 2008). Jezik komunikacije i poslovnog izveštavanja u mnogim kompanijama postaje engleski, a poslovni oglasi sve češće počinju da se objavljuju na engleskom jeziku i to na internet portalima specijalizovanim za oglašavanje upražnjenih radnih mesta. U početku samo inostrane, a vremenom i domaće kompanije, oglašavaju upražnjena radna mesta na stranom, najčešće engleskom jeziku, zahtevajući od kandidata da pokažu poznavanje pisanog i govornog engleskog jezika. Istovremeno, tekstovi oglasa se objavljuju i na srpskom jeziku, ali tokom poslednjih desetak godina uočava se tendencija da se nazivi zanimanja preuzimaju iz engleskog jezika, tako da nazivi zanimanja $\mathrm{u}$ poslovnim oglasima više ne odgovaraju zvanjima stečenim $u$ formalnom obrazovanju Republike Srbije. Preuzimanje određenih naziva zanimanja iz engleskog jezika podrazumeva i transformaciju njihovog oblika usled procesa adaptacije $\mathrm{u}$ jeziku primaocu, odnosno, u srpskom jeziku. U zavisnosti od vremena koje je proteklo od njihovog ulaska u srpski jezik, kao i od faze adaptacije $\mathrm{u}$ kojoj se nalaze, njihove obličke realizacije $\mathrm{u}$ manjoj ili većoj meri ukazuju na to da je njihovo poreklo iz engleskog jezika. Takve reči ćemo ovde posmatrati kao anglicizme, dok ćemo anglicizme koji se u srpskom jeziku javljaju u poslednjih 20 godina bliže odrediti kao novije anglicizme i u radu ćemo se baviti isključivo njima.

U radu ćemo primeniti analizu korpusa kako bismo identifikovali novije anglicizme u okviru 60 zanimanja za kojima su poslodavci pokazivali najveću potražnju oglašavajući upražnjena radna mesta u periodu od maja 2007. do kraja 2011. godine, na internet stranici www.poslovi.infostud.com. Pronađeni anglicizmi će biti klasifikovani prema realizaciji oblika u srpskom jeziku i podeljeni na sirove, očigledne, i skrivene (Prćić, 2005). Prisustvo anglicizama i njihovo učešće u korpusu oglašenih zanimanja $u$ posmatranim pojedinačnim periodima, ali i u celokupnom posmatranom periodu, poslužiće nam da ispitamo tačnost sledećih hipoteza: (H1) očigledni anglicizmi predstavljaće najbrojniju podgrupu anglicizama, usled relativno brze diversifikacije zanimanja unutar tranzicione privrede; (H2) sirovih anglicizama će u korpusu biti najmanje, a njihovi nazivi ukazuju na nepostojanje ekvivalentnog i/ili sažetog jezičkog rešenja u srpskom jeziku; i (H3) učešće novijih anglicizama $u$ ukupnom broju zanimanja $u$ najtraženijim kategorijama zanimanja beležiće konstantan rast.

\section{NOVIJI ANGLICIZMI U NAZIVIMA ZANIMANJA U SRPSKOM JEZIKU}

Filipović $(1986,193)$ ističe da su anglicizmi reči koje su preuzete iz engleskog kao jezika davaoca i koje su adaptirane $\mathrm{u}$ skladu sa sastavom jezika primaoca $\mathrm{u}$ kome se ponašaju kao "domaće reči". Skrećemo pažnju čitaocu da upliv anglicizama u zvanični jezik jedne države nije ograničen na teritoriju Republike Srbije. Naprotiv, čini se da je u pitanju pojava na globalnom nivou, koja bi mogla da se posmatra i kao neka vrsta jezičkog kolonijalizma (Filipović, 2009). Shodno tome, i u državama u okruženju, na primer, u Crnoj Gori i Hrvatskoj, primećuje se sve češća, a često i neopravdana upotreba anglicizama (Lakić, 2008), usled čega se javljaju različiti jezički problemi, naročito u pravopisu, izgovoru i prevođenju Antunović (1996). Iako pojedini autori ukazuju na problem adaptacije anglicizama u srpskom i hrvatskom jeziku, kao i na probleme standardizacije terminologije i jezičkih nedoumica nastalih usled nestandardizovane upotrebe reči stranog porekla (Filipović, 1990; Silaški, 2009a, 2009b, 2009c), pitanje upotrebe anglicizama još uvek deluje daleko od rešenja. Ovo se naročito primećuje u poslovnom životu, pogotovo tokom perioda ekonomske tranzicije, na šta ukazuju i autori koji se bave anglicizmima $u$ ekonomskoj sferi (Papović, 2000; Silaški, 2007).

U ovom radu posmatraćemo reči koje su iz engleskog jezika ušle $i$ još uvek ulaze $u$ registar naziva zanimanja u srpskom jeziku, sa ciljem da otkrijemo one anglicizme koji su se pojavili u srpskom jeziku u poslednjih 10-15 godina, pa ćemo takve reči nazvati novijim anglicizmima (od kojih se pojedini mogu naći i u Rečniku novijih anglicizama (Vasić et al, 2001)). Ako 
se uzme $\mathrm{u}$ obzir da je predmet posmatranja registar naziva profesija, kao i činjenica da je ovaj registar, $u$ uslovima tranzicione privrede, globalizacije i otvaranja tržišta, podložan promenama, stariji anglicizmi, kojih ima u nazivima zanimanja u srpskom jeziku (na primer, direktor, sekretar, itd.), mogu se smatrati adaptiranim u dovoljnoj meri da se danas i ne posmatraju kao reči potekle iz stranog jezika. Noviji anglicizmi u nazivima zanimanja, međutim, usled brzine kojom pristižu, ne uspevaju da se dovoljno brzo adaptiraju, niti da im se za semantički sadržaj koji nose dovoljno brzo nađe leksički oblik srpskoga jezika, pa se usled toga javljaju u obliku koji ne samo da zanemaruje normu već i prenebregava tvorbeni potencijal srpskoga jezika koji vremenom, bar kada su u pitanju nazivi zanimanja, postaje sve manje prisutan. Autori bi, u želji da ukažu na alarmantno veliki broj anglicizama u nazivima zanimanja, želeli da se ograde od bilo kakvih krajnjih stavova, kako jezičkog purizma tako i aplaudiranja jezičkoj nebrizi (Bugarski, 1996). Umesto toga, želeli bismo da istaknemo značaj dijaloga između poslodavaca, obrazovnih institucija, tvoraca jezičkih politika i lingvista, koji zajednički treba da rade na iznalaženju prikladnih jezičkih rešenja sa ciljem obogaćenja, ali i očuvanja, srpskog jezika.

\section{TIPOLOGIJA ANGLICIZAMA}

Klasifikacija anglicizama uslovljena je različitim namerama i potrebama autora koji se njima bave. $\mathrm{U}$ ovom radu razmatramo različite vrste novijih anglicizama $u$ pogledu njihove obličke realizacije, odnosno, u skladu sa njihovim vizuelnim identitetom koji u većojilimanjojmeriomogućava da ih prepoznamo kao reči koje se direktno prenose iz engleskog u srpski jezik, reči koje se prenose iz engleskog jezika ali se u prilagođenom obliku manifestuju u srpskom jeziku, ili, kao reči koje je teže prepoznati kao strane, ali koje na određeni način odražavaju normu ne srpskog, već engleskog jezika.

Skrećući pažnju čitaocu da postoji više načina da se anglicizmi klasifikuju (na primer, podela anglicizama prema stepenu adaptacije na primarne i sekundarne, odnosno, na anglicizme i pseudoanglicizme, koju predlaže Filipović (1986)), naglašavamo da nas u ovom radu interesuje oblička realizacija anglicizama u morfološkom, fonološkom, i ortografskom sistemu srpskoga jezika, pa ćemo primeniti onu tipologiju anglicizama koju predlaže Prćić (2005), deleći ih na sirove, očigledne i skrivene.

Sirovim anglicizmima nazivamo reči i izraze koji su iz engleskog u srpski jezik ušle u svom izvornom obliku, ne podležući primarnoj niti sekundarnoj adataciji (Filipović, 1986). Osim toga, Prćić navodi da su u ortografskom smislu ovakve reči u potpunosti neprilagođene sistemu jezika primaoca (odnosno, sistemu srpskog jezika), budući da su se integrisale samo na semantičkom planu, kao i na planu upotrebe reči u određenom kontekstu. Na morfosintaksičkom i fonološkom planu, mnogi anglicizmi se izgovaraju kao u engleskom jeziku, pa se zbog toga smatraju neprilagođenim, dok se za pojedine reči može reći da su delimično integrisane ukoliko se izgovaraju prilagođeno srpskom jeziku, ili ukoliko se u njihovom izgovoru koristi „neka englesko-srpska“ mešavina (Prćić, 2005, 121). Primer za sirovi anglicizam u čijem izgovoru nije došlo do integrisanja na fonološkom, ali ni na morfosintaksičkom planu, nalazimo u nazivu zanimanja iz kategorije odnosa sa javnošću, gde se osoba koja je zadužena za obraćanje javnosti često predstavlja kao PR (uporediti sa eng. PR) kompanije za koju radi. Kod nekih drugih sirovih anglicizama, kao što je, na primer, merchandiser, često dolazi do delimičnog integrisanja na fonološkom planu, odnosno, u izgovoru, usled drugačijeg kvaliteta suglasnika u srpskom jeziku pa se ova reč izgovara kao /merčandajzer/, sa nestandardizovanim i neutvrđenim kvalitetom glasa /č/, koji može da se čuje i kao meko /t $/$, kakvo se sreće u engleskom jeziku, dok ostali glasovi u ovoj reči manje-više odgovaraju kvalitetu glasova u srpskom jeziku.

Očigledni anglicizmi predstavljaju sledeći korak $\mathrm{u}$ adaptaciji, pošto oni podrazumevaju leksičke jedinice (uključujući i afikse) koje su preuzete iz engleskog jezika, a koje se na ortografskom, fonološkom, morfosintaksičkom, semantičkom i pragmatičkom planu ubrzano integrišu u sistem srpskog jezika, gde vremenom stiču status odomaćene, pa i domaće reči (na primer, $\mathrm{u}$ ranijem periodu direktor: eng. director, a u današnje vreme sve češće menadžer: eng. manager). 
Treću vrstu čine reči i izrazi koji, iako se javljaju u obliku primerenom srpskome jeziku, odražavaju normu i/ili slede običaje engleskog jezika (Prćić, 2005, 121), ali ih je zbog domaćeg oblika teško prepoznati kao „uvozne“, pa ih nazivamo skrivenim anglicizmima. Skriveni anglicizmi često nastaju prevođenjem (na primer, lični pomoćnik/-ica: eng. personal assistant), preoblikovanjem (na primer, administrativni asistent: eng. administrative assistant), ali i mešovitim putem, odnosno, prevođenjem i preoblikovanjem engleskog originala (na primer, asistent ljudskih resursa: eng. human resources assistant).

Imajući u vidu karakteristike sirovih, očiglednih i skrivenih anglicizama, može se smatrati da su sirovi anglicizmi najnovijeg porekla, odnosno, da su relativno skoro ušli u srpski jezik. Na isti način se može zaključiti da su skriveni anglicizmi najdalje odmakli u procesu adaptacije, budući da često sadrže leksički materijal nastao korišćenjem tvorbenog potencijala srpskog jezika. Kod očiglednih anglicizama, međutim, često nije moguće dati pouzdan sud o vremenu provedenom $\mathrm{u}$ srpskom jeziku, pošto se relativno brzo i lako odomaćuju u okviru jezika primaoca. Ovo je naročito slučaj kod pojedinih afiksa kojima su govornici često izloženi pa ih lako usvajaju (npr. sufiks -er, kao u nazivu zanimanja menadžer), ali i kod reči i izraza kojima je teško naći adekvatnu zamenu u srpskom jeziku (na primer, programer). U svakom slučaju, pripadnost određenoj vrsti anglicizama može da ukaže na relativnu starost neke reči ili izraza, kao i da pomogne u predviđanju dalje adaptacije te iste reči. Drugim rečima, ukoliko se određeni sirovi anglicizam često javlja kao naziv zanimanja u traženoj kategoriji radnih mesta, može se pretpostaviti da će on uskoro početi ubrzano da se integriše $\mathrm{u}$ jezik primalac, bilo $\mathrm{u}$ vidu očiglednog ili u vidu skrivenog anglicizma. Primer za tu pojavu ilustruje Milanović (2011) analizirajući jedan naziv zanimanja u okviru kategorije Trgovina. U pitanju je reč merchandiser (eng. merchandiser), za koju je Milanović u svom korpusu utvrdila da se javlja u sledećim oblicima: merchandiser, merčandajzer, merčendajzer (uključujući i ćiriličke oblike: мерченндајзер и мерчанндајзер), ali i kao pospešitelj prodaje. Sve obličke realizacije ove reči/sintagme su i anglicizmi, ali dok se u prvom slučaju (merchandiser) ovaj naziv zanimanja javlja kao sirovi anglicizam, $\mathrm{u}$ druga dva slučaja (merčandajzer, merčendajzer) sirovi anglicizam je preoblikovan i prilagođen fonetskom sistemu srpskog jezika. Dve varijante reči javljaju se usled nestandardizovane upotrebe ovog naziva $u$ tekstovima oglasa. Milanović $(2012,38)$ je utvrdila da se treća varijanta naziva prevedeni anglicizam, kojim se, s jedne strane, popunjava semantička praznina $u$ srpskom jeziku, pošto ne postoji domaća reč koja bi predstavljala pandan engleskom originalu, dok se, s druge strane, semantički sadržaj uvija u leksičko ruho prihvatljivo jeziku primaocu.

\section{KORPUS}

Budući da se u radu bavimo identifikovanjem novijih anglicizama $u$ nazivima zanimanja oglašenim putem interneta, analiziraćemo korpus koji obuhvata 39 kategorija radnih mesta i 60 naziva zanimanja pronađenih $\mathrm{u}$ okviru datih kategorija (korpus koji sačinjavaju radna mesta analizirana $u$ ovom radu nalazi se $\mathrm{u}$ Dodatku, $\mathrm{u}$ kome su noviji anglicizmi obeleženi masnim slovima). Sva radna mesta čiji naziv analiziramo u pokušaju da utvrdimo da li se u nazivu krije neka vrsta novijih anglicizama, pronađena su $\mathrm{u}$ poslovnim oglasima objavljenim na internet stranici www.poslovi.infostud.com u periodu od maja 2007. do kraja 2011. godine. U analizi ćemo koristiti statističke podatke koje smo preuzeli sa internet stranice www. poslovi.infostud.com, a koji nam pružaju informacije o najtraženijim kategorijama radnih mesta, kao i o naitraženijim zanimanjima $u$ okviru datih kategorija. U periodu od maja 2007. do kraja 2011. godine, objavljeno je preko 70000 oglasa u kojima se, prema podacima Infostuda (Infostud, 2009, 2010, 2011, 2012), oglašavaju radna mesta u 39 kategorija: (1) administracija i računovodstvo; (2) arhitektura; (3) bankarstvo, finansije; (4) biologija; (5) briga o lepoti; (6) dizajn; (7) opšta ekonomija (8) elektrotehnika; (9) farmacija; (10) fizika; (11) grafičarstvo, izdavaštvo; (12) građevinarstvo; (13) hemija; (14) IT; (15) jezici, književnost; (16) ljudski resursi; (17) marketing, odnosi s javnošću; (18) mašinstvo; (19) mediji, kultura; (20) srednji menadžment, (21) viši menadžment, konsalting; (22) obezbeđenje, zaštita na radu; (23) obrazovanje, briga o deci; (24) osiguranje; (25) poljoprivreda, šumarstvo; (26) pravo; (27) prehrambena tehnologija; 
(28) psihologija; (29) saobraćaj, logistika; (30) sociologija; (31) tehnologija, metalurgija; (32) telekomunikacije; (33) transport, skladištenje; (34) trgovina; (35) turizam, ugostiteljstvo; (36) umetnost; (37) veterina; (38) zaštita životne sredine; (39) zdravstvo. Osim tih informacija, izvor navodi i procentualnu zastupljenost svake od kategorija u poslovnim oglasima objavljenim $u$ jednom od 4 posmatrana perioda, koja ćemo bliže odrediti u sledećem poglavlju. Osim što nam pruža podatke o najtraženijim kategorijama i zanimanjima, izvor navodi i procentualnu zastupljenost date kategorije $u$ odnosu na sve ostale kategorije $\mathrm{u}$ toku posmatranog perioda.

Budući da su predmet interesovanja ovog rada nazivi zanimanja koji po svom obliku predstavljaju novije anglicizme, neophodno je napraviti razliku između tri grupe naziva zanimanja koje se javljaju u celokupnom korpusu:

- nazivi zanimanja na srpskom jeziku koji koreliraju sa nazivom kvalifikacija stečenih u toku srednjeg i visokog obrazovanja (na primer, metaloglodač). Primere za članove ove grupe nalazimo u sledećim nazivima: advokatski pripravnik, vatrogasac, zavarivač, itd;

- nazivi zanimanja koji su nastali pod uticajem nekog drugog jezika, najčešće engleskog, francuskog, i nemačkog, ali su se usled duge upotrebe ustalili i postali deo norme srpskog jezika. Kao deo norme, ovi nazivi našli su svoje mesto i $u$ nazivima kvalififikacija stečenih tokom srednjeg i visokog obrazovanja (na primer, diplomirani mašinski inženjer). Primer za pripadnike ove grupe nalazimo u sledećim nazivima: direktor, frizer, inženjer, itd. Među ovim nazivima, naći će se i reči koje su u srpski jezik ušle posredstvom engleskog, pa ih možemo posmatrati kao starije anglicizme;

- treću i poslednju grupu sačinjavaju nazivi zanimanja koji su, najčešće iz engleskog, u srpski jezik počeli da ulaze u poslednjih 15 godina, i taj proces još uvek traje. Ovakve reči još uvek nisu sasvim ustaljene niti normirane $\mathrm{u}$ jeziku primaocu, i kao takve javljaju se $u$ vidu novijih anglicizama. Neka od ovih zanimanja počinju da se javljaju u nazivima kvalifikacija stečenih u okviru pojedinih studijskih modula (na primer, diplomirani programer), ali određen deo naziva ostaje izvan sistema kvalifikacija, iako je prisutan na tržištu rada. Primer za pripadnike ove grupe nalazimo u sledećim zanimanjima: HoReCa menadžer (ali često i HoReCa Manager), merčendajzer (ali često i merchandiser, merčandajzer, pa čak i „мерчендајзер“), sistem inženjer (umesto inženjer informacionih sistema), i slično.

Treba napomenuti da se određen broj oglasa objavljuje na stranim jezicima, najčešće na engleskom jeziku (iako ima i oglasa objavljenih na nemačkom, francuskom, i ruskom jeziku), obično kada je oglašivač firma iz inostranstva, ili kada je u pitanju firma koja je tek ušla na srpsko tržište. Osim ove, primetne su još dve tendencije u objavljivanju oglasa:

- firme oglašavaju slobodna radna mesta tako što je veći deo oglasa napisan na srpskom jeziku, latinicom, dok je naziv radnog mesta (a ponekad i opis potrebnih kvalifikacija) napisan na engleskom jeziku, i

- treća tendencija je ona koja se najviše protivi pravopisu i pravilima posmatranog funkcionalnog stila, a odnosi se na oglase napisane ćiriličnim pismom, sa nazivom zanimanja navedenim na engleskom jeziku.

\section{METODOLOGIJA ISTRAŽIVANJA}

U radu će se primeniti analiza korpusa sa ciljem da se identifikuju noviji anglicizmi, kao i da se ispita učestalost njihove upotrebe $u$ nazivima najtraženijih zanimanja $u$ toku svakog od posmatranih perioda. Korpus će se analizirati sa ciljem da se u njemu pronađu sirovi, očigledni i skriveni anglicizmi u okviru sledeća četiri vremenska perioda, koja su odabrana na osnovu raspoloživosti podataka koje nudi izvor: Period 1 (maj 2007 - decembar 2008.), Period 2 (2009.), Period 3 (2011.) i Period 4 (2012.). Da bi se utvrdila vrsta i učešće anglicizama u najtraženijim zanimanjima posmatraće se samo one kategorije sa udelom koji premašuje 1,5\% od ukupnog broja objavljenih oglasa za posmatrani period, čime se dobija 15 kategorija po periodu (15. kategorija će obuhvatati sve oglase sa udelom manjim od 1,5\% od ukupnog broja oglasa i biće obeležena nazivom Ostalo). Ako uzmemo u obzir da se na portalu 
poslovi.infostud.com godišnje objavi više od 20000 poslovnih oglasa, na osnovu navedenog kriterijuma posmatrane kategorije se javljaju $u$ najmanje 300 objavljenih oglasa godišnje.

Podaci dobijeni analizom prisustva i učešća novijih anglicizama $\mathrm{u}$ poslovnim oglasima $\mathrm{u}$ okviru 14 najtraženijih kategorija radnih mesta, kao i podaci dobijeni podelom anglicizama na vrste, pomoći će nam da ispitamo tačnost sledećih pretpostavki:

- Hipoteza 1 (H1): Očigledni anglicizmi predstavljaće najbrojniju podgrupu anglicizama, usled relativno brze diversifikacije zanimanja unutar tranzicione privrede.

- Hipoteza 2 (H2): Sirovih anglicizama ce u korpusu biti najmanje, a njihovi nazivi ukazuju na nepostojanje ekvivalentnog i/ili sažetog jezičkog rešenja u srpskom jeziku.

- Hipoteza 3 (H3): Učešće novijih anglicizama $\mathrm{u}$ ukupnom broju zanimanja $\mathrm{u}$ najtraženijim kategorijama zanimanja beležiće konstantan rast.

\section{ANALIZA KORPUSA}

U ovom delu rada analiziraćemo korpus kako bismo utvrdili vrstu i učešće anglicizama u onim kategorijama u kojima su poslodavci najčešće oglašavali upražnjena radna mesta. Analiza obuhvata 4 perioda: Period 1 (od maja 2007. do kraja 2011. godine), Period 2 (2009. godina), Period 3 (2010. godina) i Period 4 (2011. godina).

\section{Period 1}

Najraniji podaci kojima raspolažemo u korpusu odnose se na period od maja 2007. do kraja decembra 2008. godine, u kome je objavljeno nešto više od 20000 poslovnih oglasa na internet stranici www.poslovi. infostud.com (Infostud, 2009). U toku ovog perioda, poslodavci su najčešće oglašavali radna mesta $u$ okviru sledećih 15 kategorija (Grafikon 1): (1) trgovina (16,23\%); (2) administracija, računovodstvo (10,89\%); (3) opšta ekonomija $(10,28 \%)$; (4) srednji menadžment $(6,63 \%) ;$ (5) IT $(6,32 \%) ;$ (6) građevinarstvo $(4,14 \%)$; (7) mašinstvo (3,99\%); (8) elektrotehnika (3,94\%); (9)

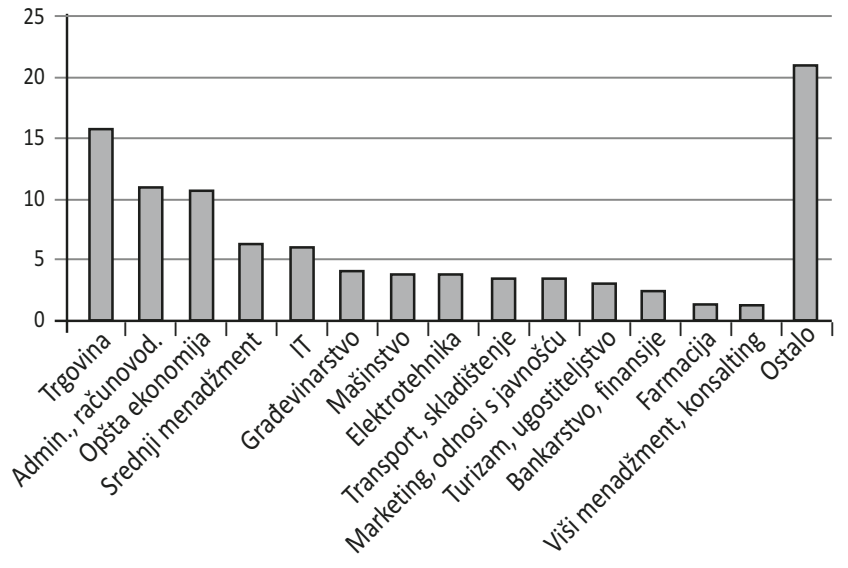

Grafikon 1 Struktura najtraženijih kategorija radnih mesta u periodu maj 2007 - kraj decembra 2008.

Izvor: Autori, na osnovu Infostud, 2009

transport, skladištenje $(3,55 \%)$; (10) marketing, odnosi s javnošću (3,54\%); (11) turizam, ugostiteljstvo (3,19\%); (12) bankarstvo, finansije (2,58\%); (13) farmacija $(1,78 \%)$; (14) viši menadžment, konsalting (1,71\%); (15) ostalo $(21,23 \%)$.

Najtraženija zanimanja u okviru ovih 14 kategorija (u 15. kategoriji nalaze se sve oblasti i zanimanja čiji je udeo u ukupnom broju objavljenih oglasa manji od $1,5 \%$ ) kod poslodavaca su sledeća zanimanja (brojevi ispred naziva zanimanja odgovaraju brojevima kategorija radnih mesta $\mathrm{u}$ okviru kojih se data zanimanja javljaju): (1) komercijalista (eng. commercial representative), prodavac; (2) knjigovođa, poslovni sekretar (eng. business secretary); (3) knjigovođa (neki nazivi zanimanja pojavljuju se u više od jedne kategorije radnih mesta, ali se u korpusu posmatraju kao jedan isti naziv zanimanja), menadžer prodaje (eng. sales manager); (4) menadžer prodaje; (5) programer (eng. programmer), sistem inženjer (eng. system engineer);; (6) građevinski inženjer; (7) mašinski inženjer, (8) diplomirani inženjer elektrotehnike, (9) vozač, magacioner; (10) saradnik u marketingu, promoter (eng. promoter); (11) konobar, kuvar; (12) saradnik, kreditni službenik (eng. loan officer); (13) diplomirani farmaceut, medicinski predstavnik (eng. medical representative), farmaceutski tehničar; (14) komercijalni direktor, HR manager (eng. HR manager), (15) ostalo 
(Infostud, 2009). Analizom teksta oglasa na uzorku od 1\% (200 oglasa) utvrđeno je da se poneka radna mesta oglašavaju na stranim jezicima (najčešće engleskom, nemačkom, francuskom, i ruskom), ali da ima i primera gde se u tekstu oglasa mešaju srpski i engleski. Međutim, budući da nije izvršen pregled oglasa na kompletnom uzorku, u ovoj analizi oslanjaćemo se samo na podatke koje nudi izvor (Infostud, 2009).

\section{Period 2}

Tokom 2009. godine, poslodavci su najčešće oglašavali radna mesta $\mathrm{u}$ okviru sledećih kategorija (Grafikon 2): (1) trgovina $(18,63 \%)$; (2) srednji menadžment $(11,44 \%)$; (3) opšta ekonomija (9,75\%); (4) administracija, računovodstvo $(9,18 \%)$; (5) IT $(5,60 \%)$; (6) bankarstvo, finansije (3,94\%); (7) marketing, odnosi s javnošću $(3,59 \%)$; (8) turizam, ugostiteljstvo (3,25\%); (9) mašinstvo $(3,07 \%) ;(10)$ elektrotehnika (2,90\%); (11) farmacija $(2,89 \%) ;(12)$ viši menadžment, konsalting $(2,26 \%) ;(13)$ transport, skladištenje $(2,22 \%)$; (14) medicina $(1,71 \%)$; (15) ostalo $(19,16 \%)$.

Analizom korpusa utvrđeno je da su tokom 2009. godine poslodavci najčešće oglašavali potrebu za sledećim zanimanjima: (1) komercijalista, prodavac; (2) menadžer prodaje, poslovođa; (3) računovođa, direktor prodaje; (4) poslovni sekretar, knjigovođa, telefonski operater (eng. call center operater); (5) programer, PHP developer (eng. PHP developer); (6) kreditni službenik, blagajnik, finansijski analitičar (eng. financial analyst); (7) marketing menadžer (eng. marketing manager), promoter, brend menadžer (eng. brand manager); (8) konobar, kuvar; (9) mašinski inženjer, bravar; (10) serviser, električar; (11) stručni saradnik u farmaciji, diplomirani farmaceut; (12) generalni direktor, izvršni direktor; (13) magacioner, vozač; (14) lekar, stručni saradnik u medicini; (15) ostalo (Infostud, 2010).

\section{Period 3}

U periodu od januara do kraja decembra 2010. godine, poslodavci su najčešće oglašavali slobodna radna mesta u okviru sledećih kategorija (Grafikon 3): (1) trgovina $(17,90 \%)$; (2) srednji menadžment $(10,87 \%)$; (3) opšta ekonomija (10,26\%); (4) administracija, računovodstvo $(8,06 \%) ;(5)$ IT (6,17\%); (6) bankarstvo, finansije $(4,04 \%)$; (7) elektrotehnika (3,71\%); (8) marketing, odnosi $\mathrm{s}$ javnošću $(3,56 \%)$; (9) mašinstvo $(3,38 \%)$; (10) turizam, ugostiteljstvo (3,17\%); (11) viši menadžment, konsalting $(2,84 \%) ; \quad(12)$ transport, skladištenje $(2,29 \%)$; (13) farmacija $(2,27 \%)$; (14) građevinarstvo (1,95\%); (15) ostalo $(13,37 \%)$.

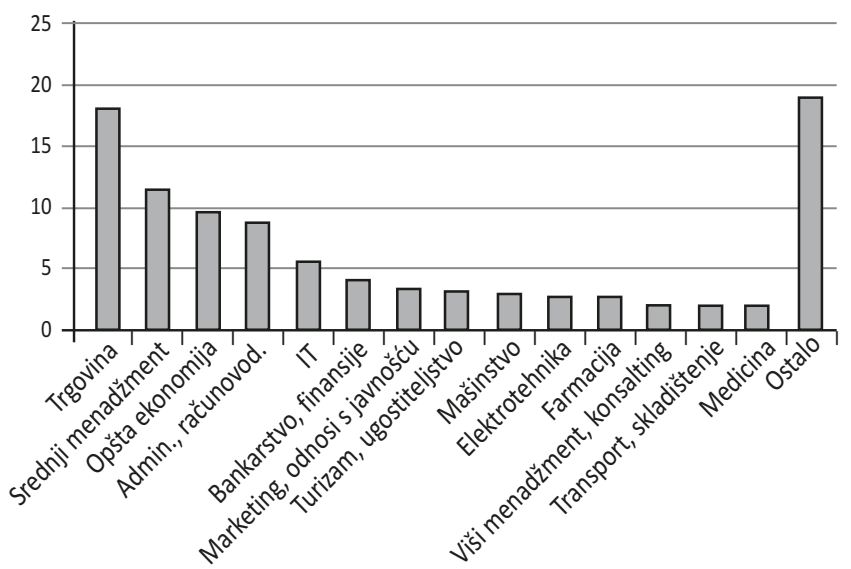

Grafikon 2 Struktura najtraženijih kategorija radnih mesta u 2009.

Izvor: Autori, na osnovu Infostud, 2010

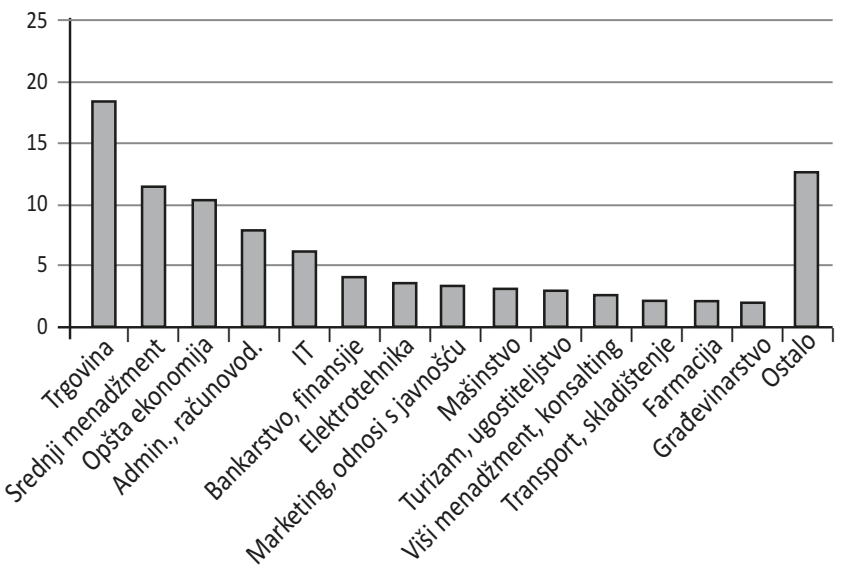

Grafikon 3 Struktura najtraženijih kategorija radnih mesta u 2010.

Izvor: Autori, na osnovu Infostud, 2011 
Tokom 2010. godine, najtraženija zanimanja u okviru prvih 14 kategorija radnih mesta obuhvatala su sledeća: (1) komercijalista, merchandiser (eng. merchandiser), prodavac; (2) menadžer prodaje i izvoza (eng. sales and exports manager), poslovođa; (3) diplomirani ekonomista, finansijski direktor; (4) administrativni radnik (eng. administrative officer), poslovni sekretar, knjigovođa; (5) administrator baza podataka (eng. data base administrator), programer, web dizajner (eng. web designer); (6) bankarski službenik; (7) serviser, električar; (8) marketing menadžer, promoter, brend menadžer (eng. brand manager); (9) mašinski inženjer; (10) menadžer ugostiteljstva (eng. hospitality manager), konobar, kuvar; (11) menadžer projekta (eng. project manager), direktor; (12) magacioner, vozač; (13) diplomirani farmaceut; (14) diplomirani građevinski inženjer, građevinski tehničar, građevinski projektant (eng. construction project engineer); (15) ostalo (Infostud, 2011).

\section{Period 4}

U periodu od januara do kraja decembra 2011. godine, poslodavci su najčešće oglašavali slobodna radna mesta u okviru sledećih kategorija (Grafikon 4): (1) trgovina $(16,66 \%)$; (2) srednji menadžment $(10,84 \%)$; (3) opšta ekonomija $(9,22 \%)$; (4) administracija, računovodstvo

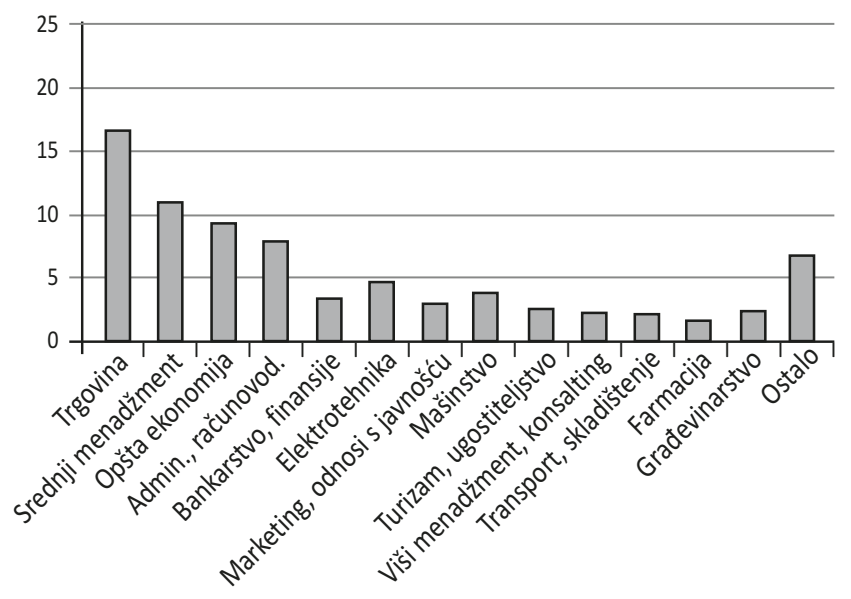

Grafikon 4 Struktura najtraženijih kategorija radnih mesta u 2011.

Izvor: Autori, na osnovu Infostud, 2012
(7,94\%); (5) elektrotehnika (4,77\%); (6) mašinstvo (3,98\%); (7) bankarstvo, finansije (3,55\%); (8) marketing, odnosi $\mathrm{s}$ javnošću (3,05\%); (9) turizam, ugostiteljstvo $(2,69 \%)$; (10) građevinarstvo (2,39\%); (11) viši menadžment, konsalting (2,27\%); (12) transport, skladištenje $(2,26 \%)$; (13) pravo $(1,86 \%)$; (14) farmacija $(1,75 \%)$; (15) ostalo $(13,37 \%)$.

Tokom 2011. godine, najtraženija zanimanja $u$ okviru prvih 14 kategorija radnih mesta obuhvatala su sledeća: (1) HoReCa menadžer (eng. HoReCa manager), merchandiser, prodavac; (2) menadžer prodaje i izvoza; (3) diplomirani ekonomista; (4) administrativni radnik, poslovni sekretar, telefonski operater; (5) serviser, električar; (6) mašinski inženjer; (7) blagajnik; (8) marketing istraživač (eng. marketing researcher), PR menadžer (eng. PR manager), PR (eng. PR), brend menadžer; (9) menadžer ugostiteljstva, glavni kuvar, kuvar; (10) diplomirani građevinski inženjer, građevinski projektant; (11) direktor; (12) kurir, magacioner, vozač; (13) diplomirani pravnik; (14) diplomirani farmaceut; (15) ostalo (Infostud, 2012).

\section{ANALIZA KORPUSA: VRSTE ANGLICIZAMA I NJIHOVO UČEŠĆE U UKUPNOM BROJU NAJTRAŽENIJIH RADNIH MESTA}

Period 1: Analizom korpusa utvrđeno je da se na spisku najtraženijih zanimanja od maja 2007. do kraja 2008. godine, u okviru 14 najtraženijih kategorija radnih mesta, nalazi 23 različita naziva zanimanja. U skladu sa odabranom metodlogijom istraživanja, i oslanjajući se na predloženu tipologiju anglicizama, utvrđeno je da se, u skladu sa načinom na koji se realizuje njihov oblik u korpusu, devet (9) naziva zanimanja mogu svrstati u grupu anglicizama. Podelom na vrste, prema tipologiji utvrđenoj u poglavlju Metodologija istraživanja, utvrđeno je da među njima ima očiglednih, skrivenih i sirovih anglicizama. Očigledni anglicizmi su: komercijalista, programer, promoter i sistem inženjer. Skriveni anglicizmi su kreditni službenik, medicinski predstavnik, menadžer prodaje, poslovni sekretar, a sirovi anglicizam je onaj koji se javlja u svom izvornom obliku HR manager (Tabela 1). Na osnovu broja pronađenih anglicizama donosi se zaključak da njihovo 
Tabela 1 Vrste novijih anglicizama u najtraženijim zanimanjima po periodima

\begin{tabular}{|c|c|c|c|c|}
\hline & Period 1 & Period 2 & Period 3 & Period 4 \\
\hline $\begin{array}{l}\text { Očigledni } \\
\text { anglicizmi }\end{array}$ & $\begin{array}{l}\text { komercijalista, programer, } \\
\text { promoter, sistem inženjer }\end{array}$ & $\begin{array}{l}\text { komercijalista, program- } \\
\text { er, finansijski analitičar, } \\
\text { marketing menadžer, } \\
\text { promoter, brend } \\
\text { menadžer }\end{array}$ & $\begin{array}{l}\text { komercijalista, admin- } \\
\text { istrator baza podataka, } \\
\text { programer, web dizajner, } \\
\text { marketing menadžer, } \\
\text { brend menadžer, } \\
\text { menadžer projekta }\end{array}$ & $\begin{array}{l}\text { HoReCa menadžer, } \\
\text { PR menadžer, brend } \\
\text { menadžer }\end{array}$ \\
\hline Skriveni anglicizmi & $\begin{array}{l}\text { kreditni službenik, } \\
\text { medicinski predstavnik, } \\
\text { menadžer prodaje, } \\
\text { poslovni sekretar, }\end{array}$ & $\begin{array}{l}\text { kreditni službenik, } \\
\text { menadžer prodaje, } \\
\text { poslovni sekretar, tele- } \\
\text { fonski operater }\end{array}$ & $\begin{array}{l}\text { administrativni radnik, } \\
\text { menadžer prodaje i } \\
\text { izvoza, poslovni sekretar, } \\
\text { menadžer ugostiteljstva, } \\
\text { građevinski projektant }\end{array}$ & $\begin{array}{l}\text { menadžer prodaje i izvoza, } \\
\text { administrativni radnik, } \\
\text { poslovni sekretar, tele- } \\
\text { fonski operater, market- } \\
\text { ing istraživač, menadžer } \\
\text { ugostiteljstva, građevinski } \\
\text { projektant }\end{array}$ \\
\hline Sirovi anglicizmi & HR manager & PHP developer & merchandiser & merchandiser, PR \\
\hline $\begin{array}{l}\text { Učešće u ukupnom } \\
\text { broju zanimanja }\end{array}$ & $39,13 \%$ & $35,48 \%$ & $46,66 \%$ & $44,44 \%$ \\
\hline
\end{tabular}

učešće u ukupnom broju pronađenih zanimanja iznosi $39,13 \%$.

Period 2: U narednom periodu, odnosno, tokom 2009. godine, u korpusu je pronađen nešto veći broj zanimanja za kojima su poslodavci pokazivali potrebu i interesovanje, pa u ovom periodu njihov broj iznosi 31. Među njima se javlja i jedanaest (11) anglicizama koji se mogu, na osnovu svog oblika, svrstati $u$ grupu očiglednih, skrivenih i sirovih anglicizama. Očigledni anglicizmi su: komercijalista, programer, finansijski analitičar, marketing menadžer, promoter, brend menadžer. Skriveni anglicizmi su: kreditni službenik, menadžer prodaje, poslovni sekretar, telefonski operater. U okviru kategorije informacionih tehnologija, pronađen je i sledeći sirovi anglicizam: PHP developer (Tabela 1). Na osnovu broja pronađenih anglicizama donosi se zaključak da njihovo učešće $u$ ukupnom broju pronađenih zanimanja iznosi 35,48\%.

Period 3: Tokom 2010. godine, broj traženih zanimanja od strane poslodavaca smanjio se za jedno zanimanje, tako da posmatrani korpus sadrži 30 naziva zanimanja, među kojima je uočeno četrnaest (14) anglicizama. Korpusnom analizom obličkih realizacija utvrđeno je da su u korpusu prisutni očigledni, skriveni i sirovi anglicizmi. Očigledni anglicizmi su: komercijalista, administrator baza podataka, programer, web dizajner, marketing menadžer, brend menadžer, menadžer projekta. Skriveni anglicizmi su: administrativni radnik, menadžer prodaje i izvoza, poslovni sekretar, menadžer ugostiteljstva, građevinski projektant. $\mathrm{U}$ korpusu je pronađen i jedan sirovi anglicizam: merchandiser (Tabela 1). Na osnovu broja pronađenih anglicizama donosi se zaključak da njihovo učešće $u$ ukupnom broju pronađenih zanimanja iznosi 35,48\%.

Period 4: U poslednjem posmatranom periodu, odnosno, tokom 2011. godine, pronađen je nešto manji broj traženih zanimanja nego godinu dana ranije, pa taj broj iznosi 27. Analizom je utvrđeno da se među pronađenim zanimanjima nalazi dvanaest (12) anglicizama, koji se mogu svrstati u očigledne, skrivene i sirove. Očigledni anglicizmi su: HoReCa menadžer, PR menadžer i brend menadžer. Skriveni anglicizmi su: menadžer prodaje i izvoza, administrativni radnik, poslovni sekretar, telefonski operater, marketing istraživač, menadžer ugostiteljstva, građevinski projektant. U grupi sirovih anglicizama našla su se dva naziva zanimanja, jedan iz prethodnog perioda (merchandiser), kao i zanimanje PR, koje $\mathrm{u}$ spisak najtraženijih ulazi tek 2011. godine (Tabela 1). Na osnovu broja pronađenih anglicizama donosi se zaključak da njihovo učešće u ukupnom broju pronađenih zanimanja iznosi $44,44 \%$. 


\section{ANALIZA NALAZA}

$\mathrm{U}$ periodu od maja 2007. do kraja decembra, 2011. analizirano je ukupno 60 različitih naziva zanimanja koja se javljaju u okviru 14 najtraženijih kategorija radnih mesta. Među zanimanjima koja su poslodavcima bila najpotrebnija našao se i određen broj (26) zanimanja čija oblička realizacija predstavlja neku vrstu anglicizama, odnosno učešce sirovih, očiglednih $\mathrm{i}$ skrivenih anglicizama $\mathrm{u}$ korpusu posmatranih zanimanja iznosi $43,33 \%$.

U Tabeli 2 prikazani su sirovi, očigledni i skriveni anglicizmi koji se javljaju u korpusu :

Tabela 2: Vrste i učešće novijih anglicizama u korpusu

\begin{tabular}{|c|c|c|c|}
\hline $\begin{array}{l}\text { Vrsta angli- } \\
\text { cizama: }\end{array}$ & $\begin{array}{l}\text { Sirovi angli- } \\
\text { cizmi }\end{array}$ & $\begin{array}{l}\text { Očigledni } \\
\text { anglicizmi }\end{array}$ & $\begin{array}{c}\text { Skriveni } \\
\text { anglicizmi }\end{array}$ \\
\hline $\begin{array}{l}\text { Anglicizmi u } \\
\text { korpusu }\end{array}$ & $\begin{array}{l}\text { HR manager, } \\
\text { merchan- } \\
\text { diser, PHP } \\
\text { developer, } \\
\text { PR }\end{array}$ & $\begin{array}{l}\text { administrator } \\
\text { baza poda- } \\
\text { taka, brend } \\
\text { menadžer, } \\
\text { finansi- } \\
\text { jski analitičar, } \\
\text { HoReCa } \\
\text { menadžer, } \\
\text { komercijalis- } \\
\text { ta, marketing } \\
\text { menadžer, } \\
\text { menadžer } \\
\text { projekta, PR } \\
\text { menadžer, } \\
\text { programer, } \\
\text { promoter, } \\
\text { sistem } \\
\text { inženjer, web } \\
\text { dizajner }\end{array}$ & $\begin{array}{l}\text { administra- } \\
\text { tivni radnik, } \\
\text { građevinski } \\
\text { projektant, } \\
\text { kreditni } \\
\text { službenik, } \\
\text { marketing } \\
\text { istraživač, } \\
\text { medicinski } \\
\text { predstavnik, } \\
\text { menadžer } \\
\text { prodaje, } \\
\text { menadžer } \\
\text { prodaje } \\
\text { i izvoza, } \\
\text { menadžer } \\
\text { ugostiteljst- } \\
\text { va, poslovni } \\
\text { sekretar, } \\
\text { telefonski } \\
\text { operater }\end{array}$ \\
\hline $\begin{array}{l}\text { Broj } \\
\text { pronađenih } \\
\text { anglicizama }\end{array}$ & 4 & 12 & 10 \\
\hline $\begin{array}{l}\text { Učešće angli- } \\
\text { cizama u \% }\end{array}$ & 15,38 & 46,15 & 38,47 \\
\hline
\end{tabular}

Uzimajući u obzir činjenicu da je analiza korpusa ukazala na prisustvo anglicizama, $u$ nastavku ćemo analizirati nalaze korpusne analize kako bismo proverili tačnost pretpostavki:

H1: Očigledni anglicizmi predstavljaće najbrojniju podgrupu anglicizama, usled relativno brze diversifikacije zanimanja unutar tranzicione privrede.

Uzimajući u obzir da je od ukupno 26 anglicizama pronađeno 12 očiglednih, 10 skrivenih i 4 sirova anglicizma, zaključuje se da je ova pretpostavka tačna pošto učešće očiglednih u odnosu na druge dve podgrupe iznosi $46,15 \%$.

U okolnostima tranzicione privrede, privatizovane i inostrane kompanije koje su se pojavile na srpskom tržištu "diktiraju“ promene koje se javljaju na svim nivoima poslovnog ponašanja, pa i na nivou zaduženja koja nosioci određenih zanimanja dobijaju unutar ovih kompanija. Kvalifikacije i zvanja stečena u okvirima formalnog obrazovanja Republike Srbije ne idu u korak sa nazivima zanimanja iz ove grupe, pa usled toga ovi nazivi zanimanja ne nose (u potpunosti) srpske nazive, iako su po obliku prilagođeni fonološkim i ortografskim pravilima srpskog jezika. Uzimajući u obzir činjenicu da se nazivi zanimanja čiji oblik predstavlja očigledan anglicizam javljaju u svim posmatranim periodima, može se zaključiti sledeće:

- za ovim zanimanjima postoji veliko interesovanje od strane poslodavaca, koje se u slučaju pojedinih zanimanja ponavlja iz godine $\mathrm{u}$ godinu (npr. komercijalista, brend menadžer, marketing menadžer, itd.).

- neka od navedenih zanimanja odražavaju postojanje potrebe da se popuni leksička praznina koja postoji u srpskom jeziku (npr. programer), dok se kod pojedinih naziva radi o jezičkoj nebrizi, pa se iz različitih (neopravdanih) razloga prenebregava postojanje srpskih ekvivalenata (npr. upravnik ili rukovodilac umesto anglicizma menadžer).

H2: Sirovih anglicizama će u korpusu biti najmanje, a njihovi nazivi ukazuju na nepostojanje ekvivalentnog i/ili sažetog jezičkog rešenja u srpskom jeziku.

U korpusu su pronađeni sledeći sirovi anglicizmi: HR manager, merchandiser, PHP developer, PR. Ako 
se uzme $u$ obzir da je ukupan broj identifikovanih anglicizama 26, sirovi anglicizmi su prisutni sa učešcem od $15,38 \%$. Ovim se potvrđuje H2.

Sirovi anglicizmi se javljaju $\mathrm{u}$ nazivima relativno skorašnjih zanimanja, za koja još uvek nije pronađeno krajnje rešenje u srpskom jeziku. Neki od ovih anglicizama, ukoliko su dovoljno često u upotrebi, mogu da se jave i u prelaznim, prilagođenim oblicima, na šta ukazuje Milanović (2011) upravo na primeru zanimanja merchandiser. Međutim, $\mathrm{u}$ našem korpusu prelazni, prilagođeni oblici nisu pronađeni. U H2 se pretpostavlja da se sirovi anglicizmi javljaju i u onim slučajevima kada srpski jezik ne nudi leksičko rešenje za dati pojam iz engleskog jezika, ili rešenje koje se nudi nije dovoljno sažeto, pa se zarad jezičke ekonomije pribegava preuzimanju sažetijeg anglicizma. Ovo možemo ilustrovati primerom anglicizma pronađenog u korpusu a koji se odnosi na zanimanje iz kategorije informacionih tehnologija: PHP developer. U pitanju je stručnjak koji se bavi razvojem PHP aplikacija, iz čega se vidi da se u srpskom jeziku ovaj pojam može jedino perifrastično opisati pošto nije moguće pronaći ekvivalentni pojam koji se, kao u originalu, sastoji od dve reči.

H3: Učešće novijih anglicizama $u$ ukupnom broju zanimanja $\mathrm{u}$ najtraženijim kategorijama zanimanja beležiće konstantan rast

Tokom prvog i trećeg perioda, anglicizmi su prisutni sa najvećim učešćem u odnosu na ukupan broj oglašenih radnih mesta, tako da njihovo učešće $u$ Periodu 1 iznosi 39,13\%, a u Periodu 3 ono iznosi 46,66\%. U drugom i četvrtom periodu učešće anglicizama u ukupnom broju oglašenih radnih mesta, ne raste već pada u odnosu na prethodni pariod, tako da u Periodu 2 ono iznosi 35,48, a u Periodu 4 njegova vrednost iznosi $44,44 \%$. Na osnovu analize korpusa i dobijenih nalaza izvodi se zaključak da $\mathrm{H} 3$ nije potvrđena, odnosno, učešće anglicizama u ukupnom broju oglašenih zanimanja ne pokazuje konstantan rast. Umesto toga, zaključuje se da nakon perioda rasta sledi period blagog opadanja. Na osnovu podataka navedenih u Tabeli 1 , može se zaključiti da određena zanimanja, koja se javljaju u obliku anglicizma, nakon određenog perioda gube na popularnosti i izlaze iz korpusa. Na primer, zanimanja kao što su sistem inženjer, HR manager, medicinski predstavnik se javljaju na spisku popularnih zanimanja $\mathrm{u}$ toku Perioda 1, a potom nestaju iz korpusa, dok neka druga zanimanja, kao što je telefonski operater pokazuju tendenciju javljanja u ciklusima (Period 2 i Period 4). Na osnovu analize se može pretpostaviti da kada se tržište zasiti određenim radnim mestima, smanjuje se njihova tražnja od strane poslodavaca.

Ukoliko dobijene rezultate posmatramo sa stanovišta nacionalne jezičke politike, može se zaključiti da je, uopšte uzev, broj anglicizama u (zabrinjavajućem) porastu. U prva dva posmatrana perioda anglicizmi se javljaju u više od $30 \%$ najtraženijih zanimanja u korpusu. U naredna dva perioda njihovo učešće raste i prelazi čak i 40\%. Nameće se zaključak da bi ovakav nagli porast upotrebe anglicizama u nazivima zanimanja mogao $u$ priličnoj meri da potisne nazive oformljene upotrebom tvorbenih sredstava srpskog jezika. U suprotnom, mogao bi se izvući poražavajući zaključak da srpski jezik nema jezičkih sredstava da popuni upražnjena leksička i semantička mesta u registru naziva zanimanja. Pojedini autori u svojim radovima (Milanović, 2011; Milanović i Milanović, 2012 a; Milanović i Milanović, 2012 b) skreću pažnju na upotrebu anglicizama $u$ pojedinim kategorijama radnih mesta, ukazujući na (ne)opravdanost upotrebe anglicizama u nazivima onih zanimanja za koja je moguće iznaći odgovarajuća i ekvivalentna jezička rešenja u srpskom jeziku.

\section{ZAKLJUČAK}

$\mathrm{U}$ ovom radu analizirali smo korpus naziva zanimanja oglašenih putem interneta, sa ciljem da identifikujemo i klasifikujemo novije anglicizme koji se javljaju $\mathrm{u}$ nazivima najtraženijih zanimanja $u$ periodu od maja 2007. do kraja 2011. godine. Pretpostavljajući da ekonomska kretanja utiču na sve sfere života, želeli smo da ispitamo u kojoj meri jezička globalizacija i sveprisutnost engleskog jezika utiču na iznalaženje odgovarajućih jezičkih rešenja $u$ registru naziva zanimanja. Ovo pitanje je blisko povezano sa postojanjem i primenom nacionalne jezičke politike usmerene na očuvanje, ali i obogaćivanje srpskog jezika, 
kome u pojedinim domenima preti anglokolonizacija, odnosno, povlačenje pred dominantnijim engleskim jezikom.

U radu smo, putem analize korpusa, testirali tri hipoteze.

Prva hipoteza kojom se tvrdi da će broj očiglednih anglicizama $u$ korpusu biti veći od druge dve podgrupe pokazala se tačnom, pošto je u korpusu koji sačinjava 60 naziva najtraženijih zanimanja prepoznato 12 očiglednih, 10 skrivenih i 4 sirova anglicizma. Na osnovu ovako velikog učešća očiglednih anglicizama (46,15\% u odnosu na druge dve podgrupe) zaključeno je da su ova zanimanja nešto duže prisutna na berzi poslova, te da za njima postoji realna potražnja ali ne i adekvatna jezička rešenja u srpskom jeziku. Usled toga, nazivi ovih zanimanja javljaju se $\mathrm{u}$ obliku (na morfološkom i fonološkom nivou) prilagođenih novijih anglicizama kako bi popunili pojedina prazna leksička mesta u srpskom jeziku. Međutim, uprkos delimičnoj opravdanosti upotrebe ovakvih anglicizama, skreće se pažnja i na prenebregavanje postojećih jezičkih rešenja srpskog jezika, koja usled jezičkog snobizma i sve češće prisutne anglocoolture (Prćić, 2005), popuštaju pred pandanima iz engleskog jezika.

Druga hipoteza $\mathrm{u}$ kojoj se navodi da ce sirovih anglicizama biti najmanje, takođe, potvrdila se $u$ analizi korpusa, $\mathrm{u}$ kojem su pronađena 4 sirova anglicizma. Njihovo prisustvo ukazuje na nedostatak leksičkih sredstava da se leksički sadržaj iz engleskog jezika adekvatno prenese u srpski jezik, koristeći se sredstvima jezika primaoca. Budući da su sirovi anglicizmi najčešće skorijeg porekla, moguće je pretpostaviti da će u narednim fazama adaptacije doći do njihovog prilagođavanja, prvo u očigledne, a zatim i skrivene anglicizme, ukoliko se za njih u međuvremenu ne pronađe odgovarajuće rešenje u srpskom jeziku.

Treća hipoteza kojom se tvrdi da će učešće anglicizama u ukupnom broju oglašenih naitraženijih zanimanja biti u konstantnom porastu nije dokazana na osnovu analize korpusa. Umesto konstantnog porasta, utvrđeno je variranje iz perioda u period, tako da je učešće anglicizama u Periodu 1 iznosilo 39,13\% , u Periodu 2 beleži blagi pad na $35,48 \%$, pa se onda ponovo beleži rast u Periodu 3 kada učešće anglicizama iznosi 46,66\% , nakon čega učešće blago pada na 44,44\% u Periodu 4. Međutim, uprkos tome što anglicizmi ne beleže porast na prelazu iz jednog $\mathrm{u}$ drugi uzastopni period, na nivou celokupnog posmatranog perioda postoji rast, pošto učešće anglicizama u prva dva perioda nije prelazilo $40 \%$ naitraženijih oglašenih zanimanja, dok u pretposlednjem i poslednjem periodu njihovo učešće premašuje $40 \%$.

Na kraju ovog rada treba ukazati na neka njegova ograničenja, kao i na potrebu sprovođenja novih istraživanja, koja bi rezultati do kojih smo došli mogla da podstaknu. Naime, u radu smo se rukovodili sređenim statističkim podacima koja nam nudi izvor, na osnovu nekoliko desetina hiljada objavljenih oglasa u periodu od maja 2007. do kraja 2011. godine. Moguće je da bi korpusna analiza kojom bi se obuhvatili tekstovi svih objavljenih oglasa dovela do nekih novih i potpunijih saznanja, naročito u pogledu postojanja prelaznih oblika anglicizama (kao što Milanović (2011) navodi slučaj zanimanja merchandiser). Osim toga, posmatrane podatke je moguće posmatrati ne samo sa stanovišta kontaktne lingvistike, već i sa stanovišta ekonomije, jezičkog i obrazovnog planiranja, i slično. Osim toga, želeli bismo da istaknemo da je jedan od razloga za saopštavanje rezultata našeg istraživanja i želja da podstaknemo dijalog između poslodavaca koji imenuju pojedina zanimanja i lingvista koji $\mathrm{u}$ tom postupku mogu da im pomognu, sa ciljem da se, izbegavajući bilo kakvo ekstremno stanovište (jezički purizam i jezičku nebrigu), srpski jezik sačuva i obogati.

\section{REFERENCE}

Antunović, G. (1996). Anglicizmi i prevođenje: bez konzultinga nema happy enda. U M. Ž. Fuchs (Ur.), Suvremena lingvistika, $\mathrm{I}-2,(1-9)$.

Bugarski, R. (1996). Uvod u opštu lingvistiku. Beograd: Čigoja štampa.

Crystal, D. (2003). English as a global language. Cambridge: Cambridge University Press. 
Dobrić, N. (2008a). Nazivi novih poslova - menadžeri. Škola biznisa II. Beograd: Visoka poslovna škola strukovnih studija.

Dobrić, N. (2008b). Uticaj engleskog na nazive poslova. U Mišić-Ilić, Lopičić (Ur.), Language, literature and globalization, (305-316).

Filipović, R. (1986). Teorija jezika u kontaktu: Uvod u lingvistiku jezičnih dodira. Zagreb: Školska knjiga.

Filipović, R. (1990). Anglicizmi u hrvatskom ili srpskom jeziku: Porijeklo, Razvoj-Značenje. Zagreb: Jugoslavenska akademija znanosti i umjetnosti - Školska knjiga.

Filipović, J. (2009). Moć reči. Beograd: Zadužbina Andrejević

Infostud. (2009). Tražena zanimanja u 2008. godini. Retrieved August 22, 2012 from Poslovi Infostud: http://poslovi. infostud.com/info/trazena-zanimanja/

Infostud. (2010). Tražena zanimanja u 2009. godini. Retrieved August 23, 2012 from Poslovi Infostud: http://poslovi. infostud.com/info/trazena-zanimanja/

Infostud. (2011). Tražena zanimanja u 2010. godini. Retrieved August 23, 2012 from Poslovi Infostud: http://poslovi. infostud.com/info/trazena-zanimanja/

Infostud. (2012). Struktura traženih zanimanja u 2011. godini. Retrieved August 23, 2012 from Poslovi Infostud: http:// poslovi.infostud.com/info/trazena-zanimanja/

Lakić, I. (2008). Anglicizmi u crnogorskom jeziku. U: Zbornik sa međunarodnog naučnog skupa „Njegoševi dani“, (321-328). Cetinje: Institut za jezik i književnost Filozofskog fakulteta

Milanović, A. (2011). Anglicizmi u nazivima zanimanja u srpskom jeziku. Neobjavljena master teza, Univerzitet u Beogradu, Filološki fakultet.

Milanović, A., \& Milanović, M. (2012a). Analiza anglicizama u nazivima zanimanja u oblastima poslovne administracije $i$ trgovine. Srpski jezik, XVII(1-2), 441-461.
Milanović, A., \& Milanović, M. (2012b). Pregled i analiza anglicizama $\mathrm{u}$ nazivima novijih zanimanja u poslovnim oglasima objavljenim na internetu. Lipar, 48, 187-201.

Novakov, P. (2008). Anglicisms in business Serbian-a linguistic and cultural transfer. In K. Rasulić, \& I. Trbojević-Milošević (Eds.), ELLSSAC Proceedings, I. (447-456). University of Belgrade, Faculty of Philology.

Papović, N. (2000). Anglicizmi u poslovnom životu. U M. Bjeletić, \& M. Vučinić (Ur.), Zbornik radova Beogradske otvorene škole, II-2 (161 - 177). Beograd: Beogradska otvorena škola.

Prćić, T. (2005). Engleski u srpskom. Novi Sad: Zmaj.

Silaški, N. (2007). Language in transition - of mergers, leverages and customisations. In B. Rakita, S. Lovreta, M. Petković(Eds.), Marketing and Management under Globalization. Proceedings of the International Scientific Conference Contemporary Challenges of Theory and Practice in Economics (361-371). Belgrade: Faculty of Economics of the University of Belgrade - Publishing Centre.

Silaški, N. (2009a). Anglicisms in Serbian business and economics discourse - is it zajedničko ulaganje, džoint venčer or joint venture?, U I. Lakić, N. Kostić (Ur.), Jezici i kulture u kontaktu - Zbornik radova (361-371). Podgorica: Institut za strane jezike.

Silaški, N. (2009b). Economic terminology in Serbian and Croatian - a comparative analysis of anglicisms. Facta Universitatis, Series: Linguistics and Literature, 7(1), (75-86).

Silaški, N. (2009c). Ka standardizaciji terminologije u oblasti marketinga i menadžmenta. Ekonomske teme, XLVII/3, (111125).

Vasić, V., Prćić, T., Nejgebauer, G. (2001). Du yu speak anglosrpski? Rečnik novijih anglicizama, Novi Sad: Zmaj 


\section{DODATAK}

Najčešće oglašavana zanimanja

(Masnim slovima označeni su noviji anglicizmi)

administrativni radnik
administrator baza podataka
bankarski službenik
blagajnik
bravar
brend menadžer
diplomirani ekonomista
diplomirani farmaceut
diplomirani građevinski
inženjer
diplomirani inženjer elek-
trotehnike
diplomirani pravnik
direktor
direktor prodaje
električar

administrativni radnik

farmaceutski tehničar

finansijski analitičar

finansijski direktor

generalni direktor

glavni kuvar

građevinski inženjer

građevinski projektant

građevinski tehničar

HoReCa menadžer

HR manager

izvršni direktor

knjigovođa

komercijalista

komercijalni direktor

konobar

kreditni službenik

kurir
kuvar
lekar
magacioner
marketing istraživač
marketing menadžer
mašinski inženjer
medicinski predstavnik
menadžer prodaje
menadžer prodaje i izvoza
menadžer projekta
menadžer ugostiteljstva
merchandiser
PHP developer
poslovni sekretar
poslovođa

PR

PR menadžer

prodavac

programer

promoter

računovođa

saradnik

saradnik u marketingu

serviser

sistem inženjer

stručni saradnik u farmaciji

telefonski operater

vozač

web dizajner
Primljeno 19. oktobra 2012, nakon revizije, prihvaćeno za publikovanje 12. decembra 2012.

Milan Milanović je lektor za engleski jezik na Katedri za anglistiku Filološko-umetničkog fakulteta Univerziteta u Kragujevcu. Završio je diplomske akademske - master studije na Filološkom fakultetu Univerziteta u Beogradu, gde pohađa nastavu na doktorskim studijama. Polja interesovanja su testiranje, evaluacija, ESP.

Ana Milanović je završila diplomske akademske - master studije na Filološkom fakultetu Univerziteta u Beogradu, gde pohađa nastavu na doktorskim studijama. Bavi se kontaktnom lingvistikom, testiranjem znanja stranog jezika, semantikom i leksikologijom. 


\title{
WHAT LANGUAGE DO EMPLOYERS SPEAK? ON RECENT ANGLICISMS IN THE NAMES OF THE MOST POPULAR PROFESSIONS ADVERTIZED ON THE INTERNET
}

\author{
Milan D. Milanovic, Ana D. Milanovic \\ Faculty of Philology and Arts, University of Kragujevac, Kragujevac, Serbia
}

\begin{abstract}
In this paper, titles of the most popular professions advertised on the Internet are analyzed for the purpose of identifying those titles which can be classified as a certain type of recent anglicisms. The classification of anglicisms is performed in line with the typology suggested by Prćić (2005), who, based on the form they take, distinguishes between raw, obvious, and hidden anglicisms, indicating the degree of their adaptation within the system of Serbian language. The following hypotheses are tested by applying corpus analysis: (1) obvious anglicisms account for the most numerous group of anglicisms in the titles of professions; (2) raw anglicisms account for the least numerous group of anglicisms; (3) the share of anglicisms demonstrates a constant growth within the most popular categories of professions in the period observed in this paper. The presence of anglicisms in titles of professions, on the one hand, implies that there are certain lexical gaps that need to be filled in so that the register of job titles can be completed, while, on the other hand, it demonstrates an alarmingly increasing number of anglicisms within the same register of Serbian language.
\end{abstract}

Keywords: recent anglicisms, job titles, Internet advertisements, Serbian language

JEL Classification: A12 